Discussion

Papers

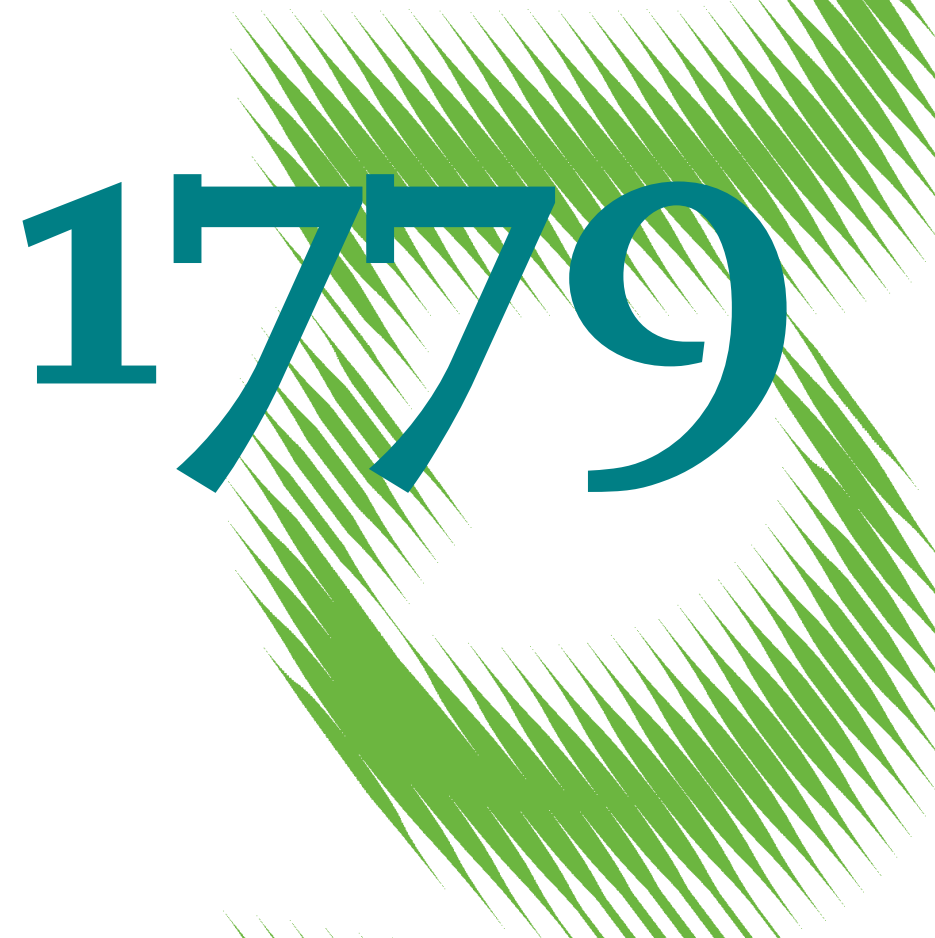

Nuclear Decommissioning after the German Nuclear Phase-Out

An Integrated View on New Regulations and Nuclear Logistics 
Opinions expressed in this paper are those of the author(s) and do not necessarily reflect views of the institute.

IMPRESSUM

(C) DIW Berlin, 2019

DIW Berlin

German Institute for Economic Research

Mohrenstr. 58

10117 Berlin

Tel. +49 (30) $89789-0$

Fax +49 (30) $89789-200$

http://www.diw.de

ISSN electronic edition 1619-4535

Papers can be downloaded free of charge from the DIW Berlin website:

http://www.diw.de/discussionpapers

Discussion Papers of DIW Berlin are indexed in RePEc and SSRN:

http://ideas.repec.org/s/diw/diwwpp.html

http://www.ssrn.com/link/DIW-Berlin-German-Inst-Econ-Res.html 


\title{
Nuclear Decommissioning after the German Nuclear Phase-Out An Integrated View on New Regulations and Nuclear Logistics
}

\author{
Tim Scherwath ${ }^{\mathrm{a}}$, Ben Wealer ${ }^{\mathrm{a}, \mathrm{b}}$, Roman Mendelevitch ${ }^{\mathrm{a}, \mathrm{c}^{*}}$ \\ a German Institute for Economic Research (DIW Berlin), Mohrenstrasse 58, 10117 Berlin, \\ Germany \\ ${ }^{b}$ Workgroup for Economic and Infrastructure Policy (WIP), Berlin University of Technology, \\ Strasse des 17. Juni 135, 10623 Berlin, Germany; \\ cHumboldt-Universität zu Berlin, Unter den Linden 6, 10099 Berlin, Germany, \\ *corresponding author: roman.mendelevitch@hu-berlin.de
}

\begin{abstract}
With Germany's nuclear phase-out, 23 reactors need to be dismantled in the near future. Initiated by the dire financial situation of the affected utilities in 2014, a major discourse on ensuring financial liability led to a redistribution of liabilities and finances, with the utilities remaining in charge of dismantling, while liability for interim and final storage now transferred to the public. This paper assesses whether the new regulation will ultimately be to the benefit of the public. It introduces a two-stage stochastic optimization framework which encompasses the different dismantling phases and resulting waste flows and storage levels of low- and intermediate-level waste (LLW and ILW) as well as the associated costs. Results show that storage risk - proclaimed as a major barrier to efficient decommissioning - is not a major driver for the optimal decommissioning schedule. However, a delay of ten years might now increase interim storage costs borne by the public by over $20 \%$. By contrast, lacking knowledge and limited machinery is a major unaccounted cost driver, which might quickly eat-up the buffer currently included in utility funds in order to deal with dismantling uncertainties. Our analysis reveals the storage gate as the new crucial interface between utilities and the public storage provider.
\end{abstract}

Keywords: Nuclear decommissioning; nuclear dismantling; financial liability; nuclear logistics; stochastic modeling; regulation

JEL-Codes: C61; H44; L51

\section{Acknowledgements}

We would like to thank Prof. Christian von Hirschhausen, Prof. Claudia Kemfert, Jan-Paul Seidel, and Theo Bietz, as well as the participants of the $6^{\text {th }}$ World Congress on Environmental and Resource Economics in Gothenburg, the $39^{\text {th }}$ Annual IAEE International Conference in Bergen and the DIW Brown Bag seminar in Berlin for their valuable comments and fruitful discussions. Ben Wealer gratefully acknowledges funding from the Heinrich-Böll-Foundation. Roman Mendelevitch gratefully acknowledges funding from BMBF. A major part of this research was performed under the DIW Berlin current topic: Nuclear Power. 


\section{Introduction}

In 2009 Germany's nuclear power plant (NPP) fleet used for commercial electricity production was given extensive lifetime extensions of up to 14 years, allowing the last reactors to operate until 2036 (German Parliament 2010, 6). Following the Fukushima Daiichi accident only two years later, the government determined the early phase-out of nuclear power, immediately revoking the operating license from eight reactors. The remaining seven reactors still connected to the grid in 2018 are gradually phasing-out until 2023 (§ 7 para. 1a AtG 2015) ${ }^{1}$. Another seven reactors have already been shut down before 2011. Every single one of these 23 reactors - located on 17 sites - must be decommissioned in the upcoming decades (cf. Figure 1 and supplementary material).

The rapid and ex-ante uncoordinated German nuclear phase-out comprises everything from a technical challenge over a political and social issue to a potential market for dismantling activities with a volume of up to 1 bnEUR per reactor (FÖS 2012; Trück and Oberle 2013). Initially, the financial liability for the entire decommissioning process was with the big four German utilities (EnBW, EON, RWE, and Vattenfall). However, initiated by the dire financial situation of the affected utilities in 2015, a major discourse on ensuring financial liability led to a redistribution of financial liabilities and responsibilities encoded in the package on the Reform of Liability in Nuclear Waste Disposal ${ }^{2}$ (German Parliament 2016b). Following the recommendations made by the commission for the review of the financing of the nuclear phase-out (KFK) utilities were now allowed to transfer the risk associated with the interim and final storage of nuclear waste to the public (German Parliament 2016a).

This paper assesses whether the new regulation will ultimately be to the benefit of the public. We contribute to the debate on nuclear decommissioning by addressing the basic need to evaluate the resulting dismantling activities, waste flows, and storage levels as well as the associated costs and potential bottlenecks. For this purpose, we set up a two-stage stochastic optimization model. At the first stage, there is the choice on the dismantling option, which determines the timing of investments in additional infrastructure as well as the timing of occurrence and amount of nuclear waste. Based on that, the second stage depicts the logistical properties of the decommissioning process focusing on low- and intermediatelevel waste (LLW and ILW). ${ }^{3}$ As an essential element of this process, the dismantling of a nuclear reactor subdivides in four dismantling phases. We take into account that each of them requires machinery and expertise mostly provided by specialized engineering and calculate the annual amount of waste produced in each dismantling phase. As cost estimates concerning the decommissioning process are partial themselves subject to uncertainties, our model serves as a valuable tool to evaluate cost estimates and highlight interdependencies between different cost parameters. The stochastic approach is used to address uncertainties associated with the opening date of the final storage facility Konrad but could also be extended to examine other types of uncertainties.

\footnotetext{
${ }^{1}$ In 2018 seven reactors are still operational with a net capacity of 9.5 GW (IAEA 2018). With a share of about $13 \%$ in electricity generation (down from an all-time high of 31\% in 1996), nuclear power plays a declining role in the German electricity mix (Frauenhofer ISE 2018).

2 Translated from German: Gesetzespaket zur "Neuordnung der Verantwortung in der kerntechnischen Entsorgung".

${ }^{3}$ Due to the high complexity and the various degrees of technical and political uncertainty (Thomauske 2015), we exclude interim and final storage of high level waste (HLW) from our analysis.
} 


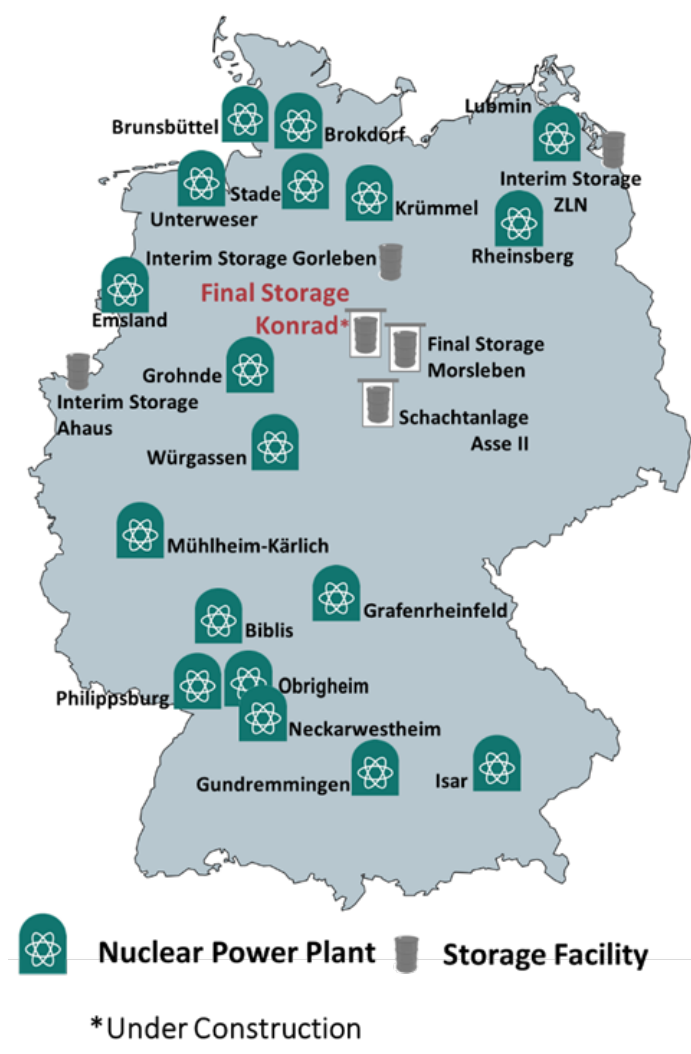

Figure 1: NPPs to be decommissioned and main centralized storage facilities in Germany.

Source: Own illustration adapted from Hirschhausen et al. (2015).

We find that it is questionable whether the new regulation will ultimately be to the benefit of the public: While unbundling dismantling activities from storage risk is one of the major goals of the new regulation, we find that in fact there is not much interdependency. Due to comparably low interim storage costs, the optimal dismantling schedule is not affected by the availability of a final storage site. Still, the public will now bear the costs of delays in completion of the final storage, which have been likely already before the reorganization of funds, but not accounted for when funds were transferred. Keeping in mind the lack of sitespecific cost estimates and frequent cost overruns, the agreed assignment of funds is unappropriated to ensure a fast and safe decommissioning process. Given this dark outlook, other organizational models for the decommissioning process should be considered that also take into account potential market concentration in the market for dismantling services.

The relevance of the German nuclear decommissioing case goes far beyond a national issue. Due to an aging global nuclear power plant fleet, there is an immanent need for exchange of best practice examples for the efficient organization of the hightech and large-scale decommissioning process which will be eventually required for all 451 existing reactors (IAEA 2018). The same applies to the newly redistributed financial liabilities and responsibilities of the Reform of Liability in Nuclear Waste Disposal (German Parliament 2016b). Addressing the issue of established utilities increasingly finding themselves in dire financial situations, while responsible to carry the financial burden of the decommissioning process is a phenomenon increasingly occurring in other nuclear nations like the U.S. and France. 
The remainder of this paper is organized as follows: The next section provides a background on the nuclear decommissioning process, aiming to give a basic understanding of fundamental technical and logistical properties as well as identifying stakeholders. Section 3 details the background on financial provisions for the decommissioning process and discusses the implications of the German Reform of Liability in Nuclear Waste Disposal. Section 4 introduces the stochastic decommissioning model, which is used for the quantitative assessment, while section 5 presents input data and discusses assumptions for the model. Section 6 provides details on model results, while Section 7 gives conclusions and policy implications.

\section{Background: The Nuclear Decommissioning Process}

At the end of the useful lifetime of a nuclear power plant (NPP), it is shut down and must be decommissioned. The decommissioning process is a multidisciplinary task that involves technical, regulatory, and organizational activities. ${ }^{4}$ A comprehensive overview of planning, execution and international experience with nuclear decommissioning is given by Laraia (2012). It comprises of dismantling the nuclear power plant, the packaging of radioactive material, and final storage in adequate repositories. ${ }^{5}$ Schneider et al. (2018) give a recent global overview of decommissioning projects, overall they identify only 19 decommissioned nuclear power plants worldwide, while only ten of them have been returned to a "greenfield". Due to high heat radiation and a mismatch between the occurrence of the waste and the availability of final storage, interim storage and conditioning of waste are also important interim steps of the decommissioning process chain. Lee et al. (2013) provide a detailed description of radioactive waste management and contaminated site clean-up following international safety and risk assessment standards and gives a global overview on existing practices. Sorenson (2012) focusses on logistical aspects and requirements for safe and secure transport and storage of radioactive materials.

\subsection{Dismantling of nuclear power plants}

Figure 2 provides a simplified scheme of the dismantling process. After the operating license of a reactor expires, it enters in the post operational phase (POP). In Germany, the regulatory framework is still the same as for an operating reactor, which limits the dismantling activities that can be executed during this phase (Scheuten 2012). Most security measures must remain active. The end of the POP is generally determined by the removal of the spent fuel from the reactor building. This significantly reduces radiation and security measures can be reduced and dismantled, respectively.

At the latest during the POP, the operator must decide on a dismantling option for each reactor. The planned activities during the chosen dismantling option must be communicated to the regulator who has to approve all activities beforehand. There are two basic options for the dismantling strategy, plus hybrid strategies that mix them:

\footnotetext{
${ }^{4}$ The IAEA Safety Glossary defines decommissioning as "Administrative and technical actions taken to allow the removal of some or all of the regulatory controls from a facility"..."Decommissioning actions are taken at the end of the operating lifetime of a facility to retire it from service with due regard for the health and safety of workers and members of the public and the protection of the environment" (IAEA 2007, 48).

${ }^{5}$ Beside of technical and organizational issue, the choice of an adequate decommissioning strategy also entails an ethical component of inter-generational justice. Surrey (1992) examines different decommissioning strategies on their ethical accounts and concludes that direct dismantling is most suitable to avoid shifting burdens to the next generation.
} 
(1) Direct dismantling

Dismantling starts as soon as possible and directly after the POP. The reactor is dismantled in four technical dismantling phases. The goal is to return to a "green field" and the release of the plant from surveillance under nuclear law.

(2) Enclosure

After the POP, the reactor is enclosed for several decades (normally for 40 years, 60 years in the U.S.) to reduce radiation and move dismantling activities to the future (deferred dismantling). The enclosure phase is followed by the same four dismantling phases, but dismantling activities are eased due to reduced radiation and consequently less waste occurs which has to be stored in a final storage facility (Leidinger 2015).

As a third, seldom applied option, entombment, i.e. the permanent on-site containment of the facility is practiced e.g. in the U.S. ${ }^{6}$

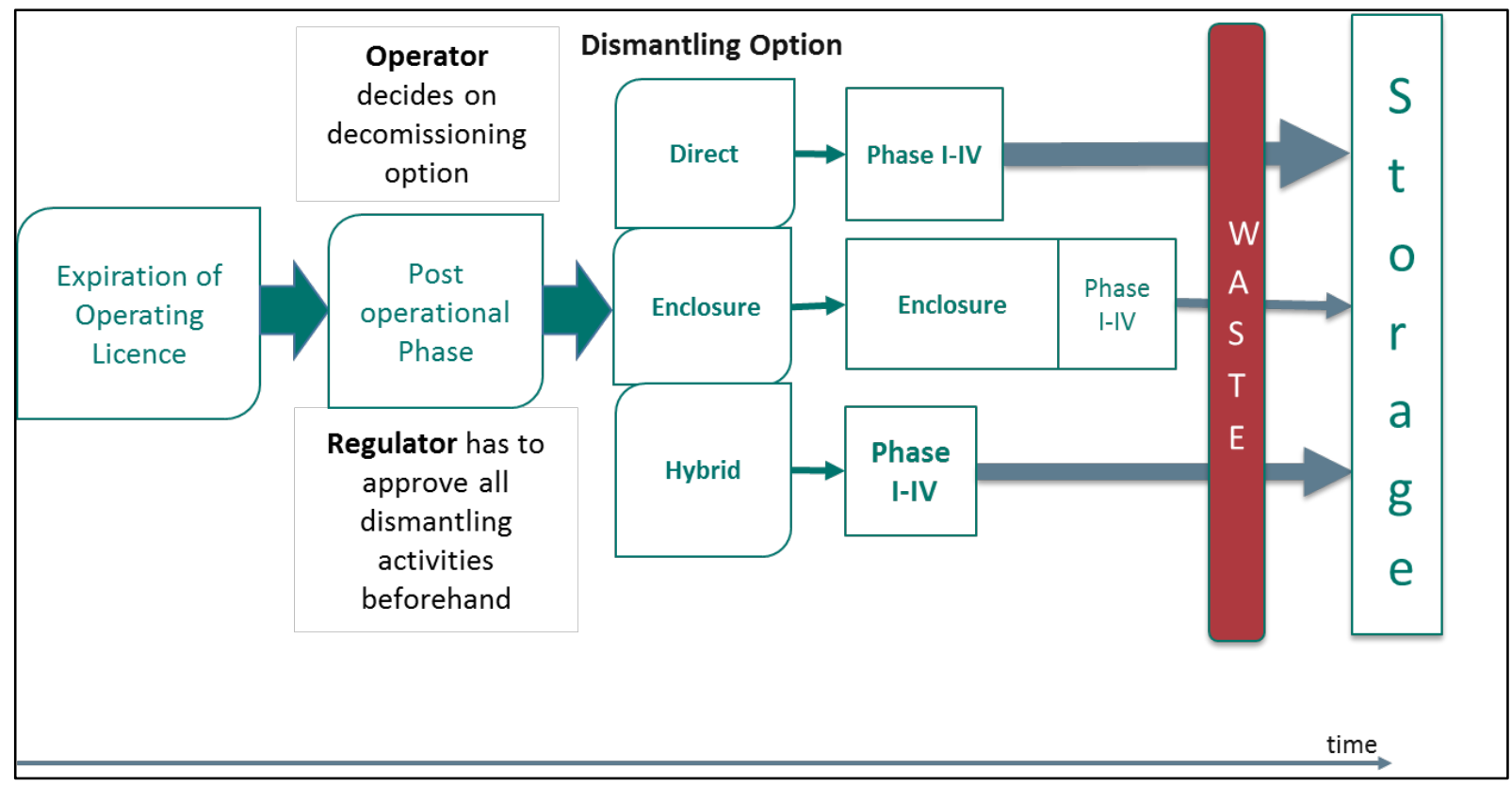

Figure 2: The Nuclear decommissioning process with different dismantling options.

Source: Own illustration based on Atomforum (2013), Bacmeister (2009), BfS (2009), EON (2008), Thierfeldt, Schartmann (2009), VGB PowerTech e.V. (2012) and Wealer et al. (2015a).

For Germany, the manual coming along with the German Nuclear Law (AtG 2015), provided by the Federal Office for Radiation Protection (BfS), prohibits entombment (BfS 2009) and the new legislation in 2016 (German Parliament 2016b, see section 4 for details) only allows direct dismantling.

The physical dismantling process moves from the outside of the reactor building towards the reactor vessel and can be subdivided into four phases (Thierfeldt and Schartmann 2009; Stahl and Strub 2012; Wealer, Gerbaulet, et al. 2015a):

\footnotetext{
${ }^{6}$ Historically, there was a vivid discussion on the right choice of the dismantling strategy for a nuclear reactor. Lough and White (1990) assess U.S. decommissioning studies on their degree of employment of formal methods and engagement with citizens. Surrey (1992) highlight the ethical dimension of the strategy choice for shifting burdens to future generation. The IAEE Energy Journal even set up a special issue on Nuclear Decommissioning Economics (1991). A detailed consideration of advantages and disadvantaged of the respective dismantling options is provided by Knack (2012).
} 
- Phase I: Decontamination and setting up of infrastructure ( 3 years)

- Phase II: Dismantling of highly activated components ( $\sim 4$ years)

- Phase III: Dismantling of pressure vessel ( 3 years)

- Phase IV: Release measurements and dismantling of buildings ( $\sim 2$ years)

Wealer et al. (2015a) and Wetzel (2016) argue that the specialized services required for the dismantling of a nuclear power plant can only be provided by few specialized companies, and therefore the German Nuclear Phase-out may create a bottleneck of required capacities (see section 2.3).

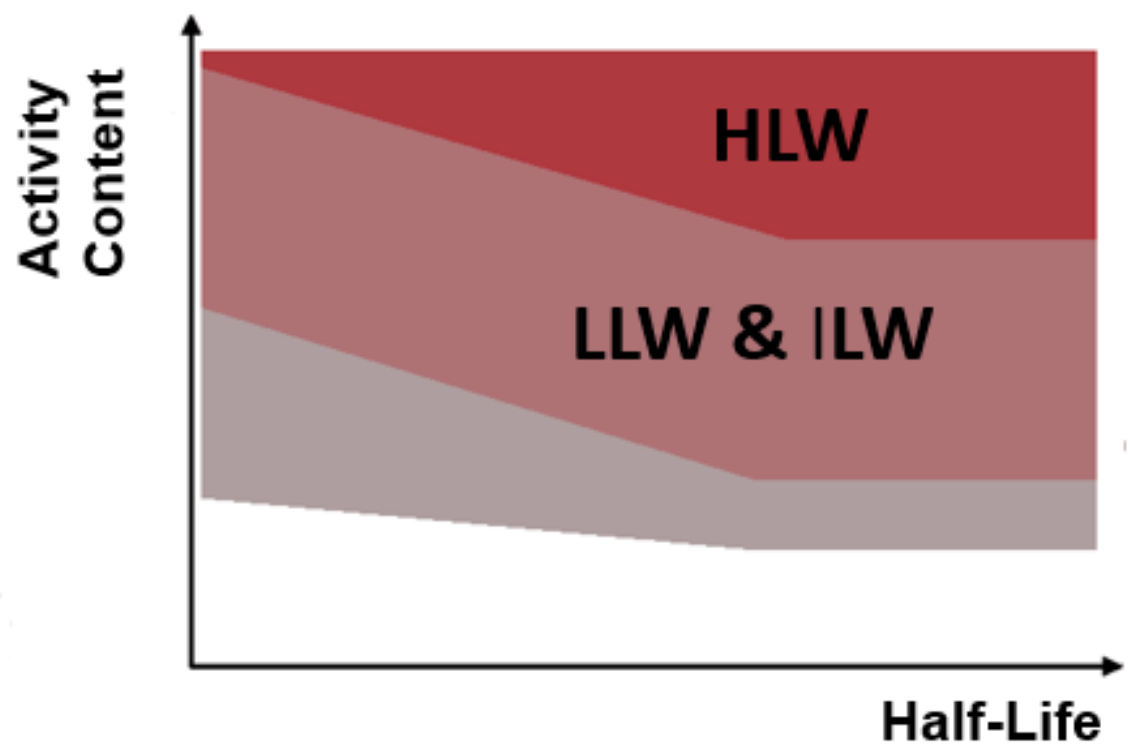

Figure 3: Classification of radioactive waste occurring during operation and dismantling of a NPP.

Souce: Own illustration based on Thierfeldt, and Schartmann $(2009,75)$.

During the dismantling process (Phases I - IV) nuclear waste is produced, which can be classified based on its radiation properties and its heat generation accordingly to Figure 3.99\% of the waste occurring from the dismantling of an NPP is LLW and ILW with negligible heat generation (VGB PowerTech e.V. 2012). ${ }^{7}$

\subsection{Packaging, Interim and Final Storage}

After conditioning and packaging in containers, which comply with the requirement of the final storage, the resulting waste from the dismantling of a reactor has a volume of $5000-7000 \mathrm{~m}^{3}$ (BfS 2015; UM 2015). The exact volume depends on the chosen dismantling option, and reactor type (see Section 2.1). In Germany, the final storage facility dedicated for LLW and ILW is located in Lower-Saxony and named Konrad. It provides a storage capacity of $303,000 \mathrm{~m}^{3}$ (see Figure 1 ).

During the negotiations for the Reform of Liability in Nuclear Waste Disposal Konrad was scheduled to open in 2022. At that time, the opening date of Konrad has already been postponed several times: Investigations of its suitability to serve as a repository for radioactive waste already started in 1977, with 2002 as the initial opening date (Brammer and Gerhards 2015). BfS (2014a, 47), and Brammer and

7 The term negligible is explained by Kunze $(2013,2)$ : “'negligible heat generation' means that the temperature on the edge of the emplacement chambers will not rise by more than $3 \mathrm{~K}$ on average due to the decay heat of the radioactive waste. 
Gerhards (2015) document the detailed development and subsequent postponing of the opening dates. Already in 2016, the opening date for 2022 was considered highly unreliable (Fritz and Kuckartz 2015; BfS 2016). Arbeitsgemeinschaft Schacht KONRAD e.V (2015) indicates several issues, like an outdated security clearance, which could lead to further delay. In 2018, the now designated builder and operator of Konrad BGE presented a new assessment report, which gives 2027 as the new opening date (BGE 2017).

While waiting for the opening of Konrad the waste must be stored in interim on-site or centralized storage facilities. Transportation of LLW and ILW can be organized via road or rail (Graffunder 2015, fol. 24).

\subsection{Market Analysis of decommissioning services}

Experiences from past and ongoing decommissioning projects show that specialized companies are especially active in Phase II and Phase III of the dismatling process where the reactor pressure vessel (RPV) and the vessel internals (RVI) are dismantled (cf. Table 1). ${ }^{8}$ As a result of the highest requirements in radiation protection and know-how in dismantling and disassembly, these turn out to be the most complex and specific tasks. ${ }^{9}$

The market for nuclear decommissioning and waste management services required in Phase II and Phase III is highly concentrated. The following table provides an overview of the involved companies in the different stages of the German decommissioning process.

In addition to the companies already active in Germany, a few companies have already shown interest in entering the Germany market. In 2017, GE Hitachi Nuclear Energy (GEH) and Bechtel announced the formation of an alliance to offer the full spectrum of decommissioning activities to enter the German and Swedish decommissioning market (Bechtel 2017). Another international joint-venture with concrete plans to offer integrated decomissioning services in Germany is the alliance of Westinghouse and Hochtief (Westinghouse 2015b). In 2017, six years after the first shut-down wave some utilities have already procured services for the dismantling of the RPV and/or the RVI: Vattenfall awarded the contract for the dismantling of the RVI to a consortium of EWN and Areva, with an option for the Krümmel plant (AREVA 2017). EnBW awarded a contract for the dismantling of the RPV and RVI to a Westinghouse-led consortium with Nukem Technologies and GNS (Westinghouse 2015a). PreussenElektra contracted Areva for decontamination services for its Isar-1 NPP (Wasinger 2015). In January 2018, PreussenElektra awarded a decommissioing contract to Zerkon - a consortium led by the German utilities-owned waste management company $\mathrm{GNS}^{10}$ and Westinghouse Electric Sweden -to dismantle the RVI of its six plants (Schneider et al. 2018).

\footnotetext{
${ }^{8}$ Most parts of a nuclear power plant never become radioactive during operations and can therefore be dismantled or removed using conventional methods. Consequently, these tasks - especially in the Phases I and V - can be executed by conventional companies from the construction sector.

${ }^{9}$ The disassembley is partially executed under water or with the help of manipulators. The situation in the German NPP Stade is examplary, where it turned out that nearly all tools used in the Phase III had to be designed especially for that purpose (Wealer, Gerbaulet, et al. 2015b, 41).

${ }^{10}$ PreussenElektra is the major shareholder of GNS with 48 percent of the shares.
} 


\begin{tabular}{|c|c|c|c|c|c|}
\hline $\begin{array}{l}\text { NPP and current } \\
\text { stage }\end{array}$ & Phase I & Phase II & Phase III & Phase IV & $\begin{array}{c}\text { Overall } \\
\text { Involvement }\end{array}$ \\
\hline $\begin{array}{l}\text { Niederaichbach } \\
\text { (completed) }\end{array}$ & & $\begin{array}{l}\text { Babcock } \\
\text { Noell and } \\
\text { EWN }\end{array}$ & & & \\
\hline VAK Kahl (complted) & & NIS & NUKEM (RVI), NIS & NIS & \\
\hline $\begin{array}{l}\text { Würgassen } \\
\text { (completed) }\end{array}$ & & & Areva GmbH (RVI) & & Siempelkamp \\
\hline $\begin{array}{l}\text { Gundremmingen A } \\
\text { (completed) }\end{array}$ & & & NUKEM & & \\
\hline Stade (Phase IV) & & $\begin{array}{c}\text { GNS } \\
\text { Studsvik }^{11}\end{array}$ & $\begin{array}{l}\text { Areva GmbH (RVI), } \\
\text { NIS mit EON (RPV) }\end{array}$ & & Sat. Kerntechnik \\
\hline $\begin{array}{l}\text { Greifswald } 1+2 \\
\text { (Phase IV) }\end{array}$ & & & EWN (RVI, RPV) & & EWN \\
\hline $\begin{array}{l}\text { Greifswald } 3-5 \\
\text { (Phase IV) }\end{array}$ & & & $\begin{array}{c}\text { Mammoet transport } \\
\text { to ZLN }\end{array}$ & & EWN \\
\hline Obrigheim (Phase III) & & $\begin{array}{c}\text { Babcock } \\
\text { Noell and } \\
\text { EWN }\end{array}$ & EWN (RVI, RPV) & & \\
\hline $\begin{array}{l}\text { Mülheim-Kährlich } \\
\text { (Phase III) }\end{array}$ & & $\begin{array}{c}\text { Sat } \\
\text { Kerntechnik }\end{array}$ & & & Siempelkamp \\
\hline Jülich (Phase III) & & & $\begin{array}{l}\text { Mammoet removal of } \\
\text { the RPV for storage }\end{array}$ & & EWN \\
\hline Biblis A (Phase I) & NIS & & & & \\
\hline KNK II (Phase III) & & & EWN & & EWN \\
\hline $\begin{array}{l}\text { MZFR Karlsruhe } \\
\text { (Phase IV) }\end{array}$ & & & EWN & & EWN \\
\hline
\end{tabular}

Table 1 - Companies involved in the different decommissioning stages in Germany ${ }^{12}$.

Source: Own illustration based on Wealer et al. (2017).

To conclude, the following six companies, have experiences in Germany or have concrete plans to enter the German market ${ }^{13}$ : Nukem Technologies; Areva; EWN; Siempelkamp; GEH; Westinghouse; Babcock. Trying to reap economies of scale and collaborating in work on the most critical components it is reasonable to assume that not more than five German RPV can be handled simultaneously.

\section{Financial Provisions and the Reform of Liability in Nuclear Waste Disposal ${ }^{14}$}

Concerns that utilities may go out of business without leaving sufficient funds set aside in an independent fund to finance the full decommissioning process are not a new issue. In a world-wide survey of civil decommissioning activities, Bradbury (1992) identifies inadequacies of funding provision as one of the sources for delays in decommissioning plans. In fact, concerns on the adequate funding were the main drivers of reviews of regulation on decommissioning (cf. Surrey 1992; LaGuardia and Murphy 2012). Williams (2007) assesses the funding adequacy for the U.S. on a reactor basis for the period 1998 to 2004 and finds mixed results. LaGuardia and Murphy (2012) provide a historical background and the current

\footnotetext{
${ }^{11}$ GNS transported the steam generators to Studsvik in Sweden.

12 Grey cells are completed phases.

13 There are other international companies like Cavendish Nuclear Services, CH2M Hill, or Fluor that have the necessary know-how to do the services, but they have no experience in Germany and are already heavily involved in the decommissioning of 30 reactors in the UK and have yet not expressed any interest in entering the market.

${ }^{14}$ German: Gesetzespaket zur „Neuordnung der Verantwortung in der kerntechnischen Entsorgung“.
} 
state of financing nuclear decommissioning and present the methodology used for the economic assessment of the process in different countries.

In Germany, costs, financial provisions and risks of the decommissioning process came back into focus in 2014, driven by the German Nuclear Phase-out and the dire financial situation of the major energy utilities. Provisions made by the German utilities to cover both processes, the entire decommissioning and subsequent waste management, sum up to an amount of 38.3bn EUR by the end of 2014 (Wieland-Böse and Jonas 2015a, 5). By contrast, total decommissioning and waste management liabilities have a net present value (NPV) of 38.5bn - 77.4bn EUR 2014 (depending on the interest rate applied, Wieland-Böse and Jonas 2015b, 68-69). Seriously in doubt whether available funds and the institutional arrangements at that time were adequate to ensure a fast and safe decommissioning process, several publications address the need to restructure the organizational model and to consider its impact on the allocation of costs and risks (Küchler, Meyer, and Wronski 2014; Hirschhausen, Gerbaulet, Kemfert, Reitz, and Ziehm 2015).

\subsection{Background on the legislative package}

As a reaction to these concerns and the evolving public debate, the German government installed a commission that was charged with reviewing the funding for the nuclear phase-out ("Kommission zur Überprüfung der Finanzierung des Kernausstiegs (KFK)), in October 2015. At that time, the four German utilities owning the nuclear power plants were in full financial charge for the entire decommissioning process. It was already clear that not only did the costs of these processes exceed the provisions made by companies, but also that rigorously applying the "polluter-pays" principle would push all four utilities into bankruptcy (Kunz et al. 2018) $)^{15}$.

Against this background, the goal of the commission was to secure the funding for an adequate disposal and to disentangle it from the economic situation of the companies (KFK 2016). The commission presented its recommendations in April 2016 and in December 2016 the German parliament voted for a package on the Reform of Liability in Nuclear Waste Disposal (Gesetzespaket zur "Neuordnung der Verantwortung in der kerntechnischen Entsorgung“, German Parliament 2016b) that follows these recommendations. As a core element, utilities could now transfer liability and financial responsibility for interim and final storage to the public. In return, an amount of 23.6bn EUR (4.7bn EUR 2014 for interim storage and 12.5bn EUR 2014 for final storage plus a risk premium of $35.47 \%$ ) had to be released into public funds. Utilities still remain liable for dismantling of the reactors and packaging of occurring waste (KFK 2016; German Parliament 2017). Utilities have already transferred funds in due course (BMWI 2017).

Table 2 summarizes the new split of responsibilities, resulting intended and unintended incentives and potential pitfalls following from the new package, which are discussed in more detail in the subsequent subsections.

\footnotetext{
${ }^{15} \S 9$ of the German Atomic Energy Act stipulates that operators of nuclear generation units have to ensure sufficient provisions for the safe long-term storage of nuclear waste from operation.
} 
Table 2: Summary of split of responsibilities, implied incentives and potential pitfalls following from the new package on the "Reform of Liability in Nuclear Waste Disposal"

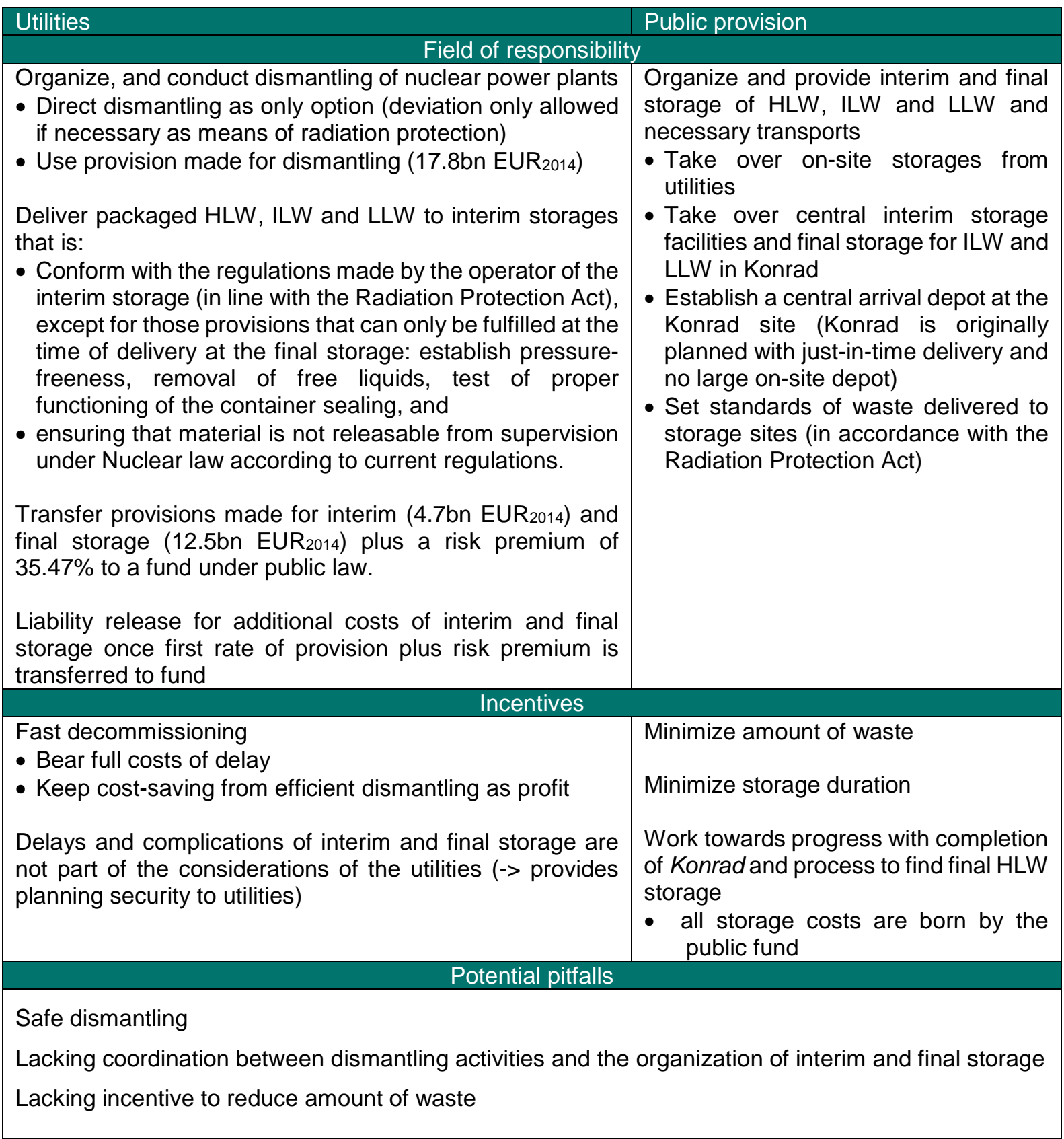

In the following, we want to focus on some of the central point of the discussion and elaborate on the reasoning behind them.

\subsection{Split of responsibility for dismantling and packaging vs. interim and final storage and transport}

The split in responsibilities for the decommissioning process was based on the idea of aligning incentives, ownership and control for the respective steps of the entire process. It is in the interest of the public to ensure that the dismantling process is performed by the utilities as fast as possible. On the one hand, this process step is directly succeeding operation and the risks that can occur during this phase can be best assessed with the know-how and experience of the current operators and their specialized partners. On the other hand, the dire financial situation of the utilities possibly undermines provisions made for 
decommissioning. Therefore, this task should be performed as soon as possible. By keeping the responsibility for dismantling with the utilities on the one hand, they bear the full costs of delays with this process step. On the other hand, they can keep cost-savings from dismantling and transfer current provisions into assets, which provides incentives for an efficient conduct.

By unbundling the dismantling stage from the downstream interim and final storage, the utilities are not affected by delays and complications of interim and final storage, anymore. This provides planning security to utilities and works against arguments of cost escalation and deferral of dismantling.

\subsection{Value of integrated planning and unaccounted dismantling risks}

Before the reform package was enacted, the German Nuclear law allowed a choice between the direct decommissioning and "safe enclosure" or more correctly long-term enclosure strategy. This choice allows to trade-off between higher upfront costs for the enclosure and the reduction in amounts of ILW and LLW due to natural decay, as compared to direct dismantling. When optimizing the entire decommissioning process also across all reactors that need to be decommissioned, expected downstream risks (e.g. availability of a final repository) could influence the cost optimal scheduling of dismantling activities or choice of dismantling option. If the responsibility is separated, coordination is less likely and could thus induce higher costs.

Although, utilities will have the incentive to achieve cost-savings, these are not very likely. Previous dismantling and interim storage projects exhibit cost overruns by $2.9 \%$ und $6 \%$, which are higher than the sum of inflation (1.6\%) and nuclear specific cost escalation (1.97\%) assumed on average in the provision of the utilities (cf. Wieland-Böse and Jonas 2015a). Another cost driver could be the concentration of dismantling activities (i.e. scale effects), which requires specialized engineering equipment, and know-how which is currently only provided by a few firms, world-wide (cf. Section 2.3). Our model results confirm that coordination between the different dismantling projects is required if historical dismantling capacities are compared against expected dismantling activities resulting from the current regulation for direct dismantling. (cf. results in Section 6)

According to the new regulation, utilities will still have to bear the full costs including potential cost overruns for the dismantling and packaging stages. If the dire financial situation of the utilities prevails the dichotomy between achieving a fast and a safe dismantling process may increase.

\subsection{Interface of delivery of waste between utilities and storage provider}

Due to the unbundling of the upstream dismantling and the mid- and downstream interim and final storage, the regulations on the waste delivered to the interim storage sites will be the crucial element of interaction between the private utilities and the public storage provider. While packaging and reducing amounts of waste is associated with undesired costs for the utilities, minimizing storage costs, and thus volumes is key for the new public storage provider. The new law prescribes that the storage provider must specify regulations for waste admissible to the storage, which have to confirm with the Radiation Protection Act. From the perspective of the storage provider, these standards have to create a total stream of waste, which is compatible with the already fixed maximum storage capacity of Konrad of $303,000 \mathrm{~m}^{3}$. 
This interaction will be further complicated by a new European Directive which is likely to affect the amount of waste which can be released from the surveillance under the German Nuclear Law (directive 2013/59/Euratom, EC 2014). It is likely to increase the volumes of waste that require additional treatment and therefore either increase costs of dismantling or volumes of waste to be stored (see Supplementary Material for more details).

\section{Methodology: A Stochastic Model of the Nuclear Decommissioning Process}

Various models have been developed to study the multi-objective problem of hazardous waste location and routing (see e.g. Samanlioglu 2013; Ghiani et al. 2014). Hawickhorst (1997) and Hwang et al (2003) setup optimization tools for the management of radioactive waste from the operation of nuclear power plants. The high demand for future dismantling of NPPs is addressed by Bartels et al. (2011), where the NPV of a dismantling project is optimized by using a resource-constrained project scheduling approach. In a reverse logistics approach that considers both the nuclear power generation and the corresponding induced waste reverse logistics, Sheu (2008) addresses the effcient and cost-minizing organization of nuclear waste disposal during operation, while taking into account operational risks.

To our best knowledge, the model we present in this paper is the first to represent the decommissioning process in sufficient details to track the effect of dismantling activities on the flow and storage of LLW and ILW, on investments in additional on-site storage facilities, and most important on the associated cost. We apply our model to evaluate the financial and logistical consequences of the rapid shut down of Germany's NPPs. Moreover, we use it to gain insights on the effects of the Reform of Liability in Nuclear Waste Disposal.

\subsection{General concept}

The flow chart in Figure 4 depicts the model implementation of the decommissioning process as it is described in section 2. We set it up as a two-stage decision process: on the first stage, a choice on the dismantling option for each reactor is taken. This option determines the sequence in which a reactor runs through the different phases of dismantling and the respective amounts of waste that occur during the process. This decision has to be taken as soon as the operating license of a reactor expires (within the same model period). For calculations carried out in this paper, direct dismantling is the only available option, but the course of dismantling phases can be delayed by adding waiting periods. This might become necessary if there is still uncertainty about key characteristics like availability of a final storage, or available dismantling capacities, at that point in time.

Conditioned waste occurring during dismantling Phase I to Phase IV on-site can then be transported through the network towards the final storage facility (Konrad) or be stored in intermediate on-site or central storage facilities. Decisions on the transportation and storage of waste are determined in the second stage, once uncertainties have resolved. 


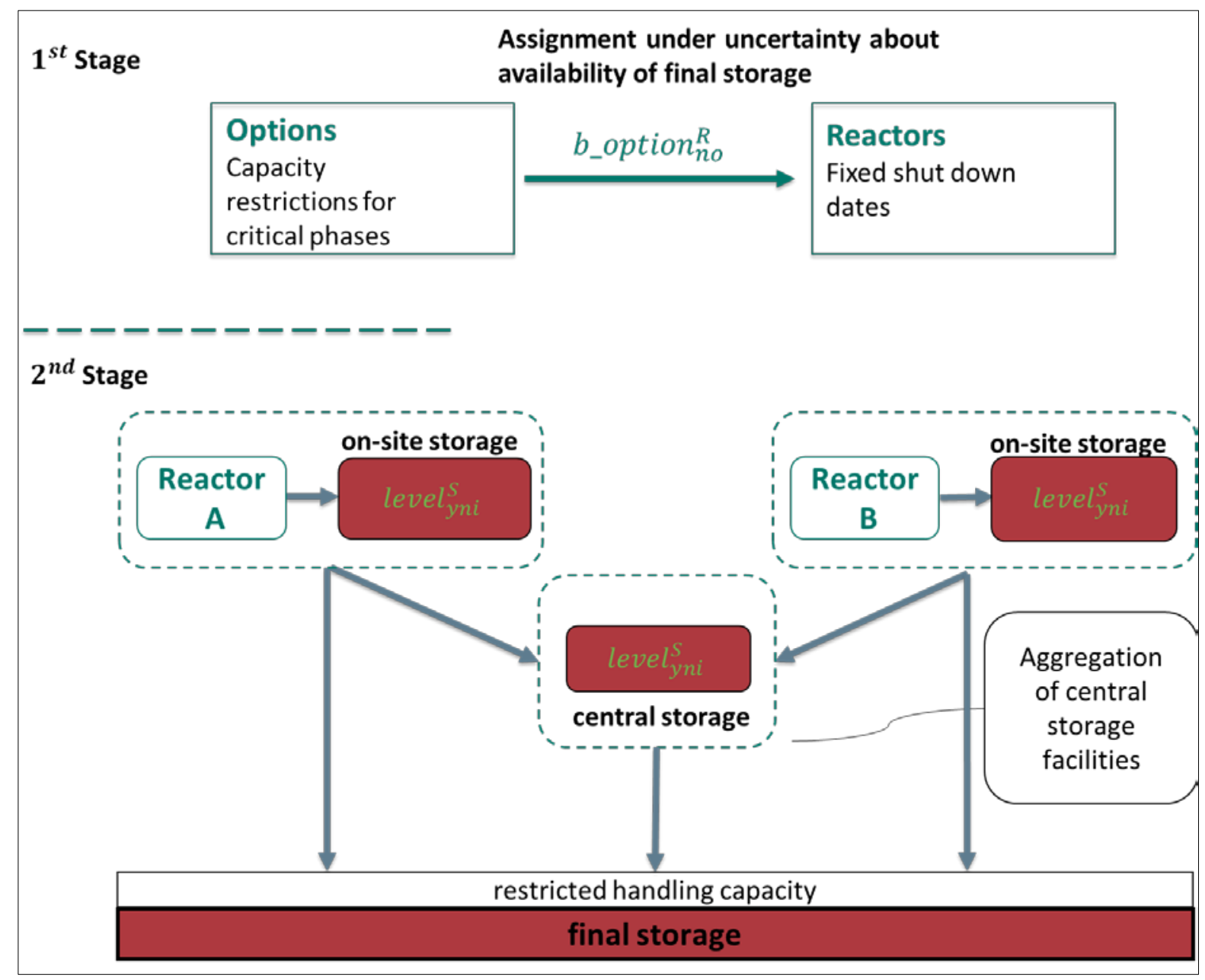

Figure 4: The decommissioning process as a two-stage stochastic optimization model.

To incorporate uncertainty in the first stage of our model framework we follow the approach described by Birge and Louveaux (2011). The second stage has the properties of a classical transport problem. Equations for the nodal flow balance and capacity restrictions for the storage level are adapted from Coelho et al. (2012). In our application, the commodity transported through the network of reactors and storage facilities is nuclear waste. The resulting mathematical problem constitutes a mixed integer stochastic program.

A plain English description of the algebraic formulation of the model is presented the following section.

\subsection{Model description}

A full description of the model sets, parameter, scalars and variables can be found in Table A1 in the Appendix. In the following notation parameters are given in capital letters and variables are given in bold.

\section{Objective function}

$\min z=$

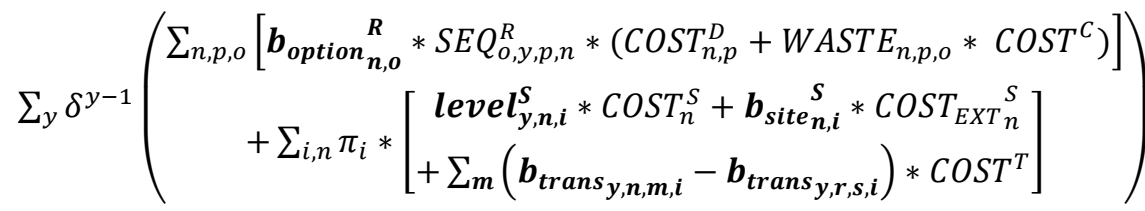


The objective function (1) minimizes the total costs of the decommissioning process discounted by $\delta^{y-1}$. It splits into two parts with two different types of decision horizons:

- Decision on dismantling activities under uncertainty (1 ${ }^{\text {st }}$ Stage)

In the first part, a decision on the decommissioning option $\boldsymbol{b}_{-} \boldsymbol{o p t i o n _ { n , o } ^ { R }}$ is made under uncertainty about the realization of different scenarios. Each option entails a predefined sequence of dismantling phases $S E Q_{o, y, p, n}^{R}$. In each year $y$, resulting dismantling costs $\operatorname{COST}_{n, p}^{D}$ depend on the reactor type (each reactor is assigned to an individual node $r(n)$ ) and on dismantling phase $p$. Moreover, the option-, reactor- and phase-specific amount of waste WASTE $E_{n, p, o}$ needs to be packaged into containers that are suitable for storage, which entails container costs $\operatorname{CoST}^{C}$.

- Decision on storage and transport of LLW and ILW ( $2^{\text {nd }}$ Stage)

In the second part, a scenario $i$ has realized. Still operational decisions can be made on: i) the storage level in different storage sites level $_{y, n, i}^{S}$ (which all entail storage costs $\operatorname{COST}_{n}^{S}$, except for storage in Konrad, the final deposit), ii) the extension of on-site storage $\underset{\boldsymbol{b}_{\text {side }}, \boldsymbol{s}}{\boldsymbol{s}}$ (entailing investment costs COST_EXT $T_{n}^{S}$ ), and iii) transshipment of waste $\boldsymbol{b}_{-}$trans $\boldsymbol{s}_{\boldsymbol{y}, \boldsymbol{n}, \boldsymbol{m}, \boldsymbol{i}}$ between different storage sites (entailing administrative costs of $\operatorname{COST}^{T}$ for each shipment) ${ }^{16}$. The costs of each scenario are weighted according to the probability its of occurrence $\pi_{i}$.

\section{$\underline{\text { Constraints }}$}

Equ. (2) assigns one dismantling option to each reactor. The choice can be restricted by the availability of dismantling services for each phase $C A P_{p, y}^{D}$ (3).

$$
\begin{gathered}
\sum_{o} b_{-} o p \operatorname{tion}_{r, o}^{R}=1 \forall r \in n \\
\sum_{n} b_{-} \text {option }_{n, o}^{R} * S E Q_{o, y, p, n}^{R} \leq C A P_{p, y}^{D} \forall o, p, y
\end{gathered}
$$

Each dismantling plan result in a distinct schedule of generated waste that needs to be stored. Equ. (4) gives the nodal balance of LLW and ILW waste in each year and for each scenario. At any storage site, current storage level level $_{y, n, i}^{S}$ has to equal storage level from previous period $\operatorname{level}_{\boldsymbol{y}-1, n, \boldsymbol{i}}^{S}$ plus waste generated at the site in this period $W A S T E_{p, n}$ (which depends on the chosen decommissioning option $\boldsymbol{b}_{-} \boldsymbol{o p t i o n}_{n, \boldsymbol{o}}^{R}$ and the entailing sequence of dismantling phases $S E Q_{o, y, p, n}^{R}$ and reactor type). Furthermore, waste can be shipped between different sites (i.e. between on-site storage, central storage and final storage, where possible routes are indicated by the adjacency matrix $\left.A_{n, m}\right) \cdot{ }^{17}$

While the decision on the decommissioning option has to be taken under uncertainty about key determinates, the uncertainty resolves only in year $Y_{-} K_{i}$. Therefore, assuming a stochastic approach, also

\footnotetext{
${ }^{16}$ As on-site storage facilities are located close to the reactor, we subtract the number of transports from reactors to on-side storage facilities.

17 The initial storage level for each storage site is assigned by: $\operatorname{level}_{Y-S, n, i}^{S}=\sum_{o, p}\left(\boldsymbol{b}_{-} \boldsymbol{o p t i o n} \boldsymbol{n}_{n, \boldsymbol{o}}^{R} * S E Q_{o, y, p, n}^{R} *\right.$ $\left.W_{\text {ASTE }}, n\right)-\sum_{m}\left(\operatorname{trans}_{\boldsymbol{n}, \boldsymbol{m}, \boldsymbol{y}, \boldsymbol{i}} * A_{n, m}\right)+\sum_{m}\left(\operatorname{trans}_{\boldsymbol{m}, \boldsymbol{n}, \boldsymbol{y}, \boldsymbol{i}} * A_{m, n}\right)+\operatorname{INIT}_{n}^{S}$.
} 
the operational decision variables level $_{y, n, i}^{S}$ and $\operatorname{trans}_{n, m, y, i}$ have to be consistent between the different scenarios, before the uncertainty resolves. Equs. (5) and (6) ensure that the former condition holds.

$$
\begin{aligned}
& \text { level } l_{y, n, i}^{S}= \\
& \text { level }_{\boldsymbol{y - 1 , n , \boldsymbol { i }}}^{S}+\sum_{o, p}\left({\boldsymbol{b} \_o p t i o n_{n, \boldsymbol{o}}^{R}}_{\boldsymbol{R}}^{\boldsymbol{R}} * S E Q_{o, y, p, n}^{R} * W A S T E_{o, p, n}\right)-\sum_{m}\left(\boldsymbol{t r a n s}_{\boldsymbol{n}, \boldsymbol{m}, \boldsymbol{y}, \boldsymbol{i}} * A_{n, m}\right) \\
& +\sum_{m}\left(\operatorname{trans}_{\boldsymbol{m}, \boldsymbol{n}, \boldsymbol{y}, \boldsymbol{i}} * A_{m, n}\right) \forall y, n, i \\
& \text { level }_{\boldsymbol{y}, \boldsymbol{n}, \boldsymbol{i}}^{S}=\text { level }_{\boldsymbol{y}, \boldsymbol{n}, \boldsymbol{j}}^{S} \forall i, j, n, y ; \boldsymbol{F O R}: y<Y_{-} K_{i} \\
& \operatorname{trans}_{\boldsymbol{n}, \boldsymbol{m}, \boldsymbol{y}, \boldsymbol{i}}=\boldsymbol{t r a n s}_{\boldsymbol{n}, \boldsymbol{m}, \boldsymbol{y}, \boldsymbol{j}} \forall i, j, n, m, y ; \boldsymbol{F O R}: y<Y_{-} K_{i}
\end{aligned}
$$

Annual storage of LLW and ILW waste at each site cannot exceed storage capacity $C A P_{n y}^{S}$ (cf. Equ. 7). For on-site storage, extension of storage capacity by $\operatorname{EXT}_{n}^{S}$ is possible. Storage inflow is also restricted by a maximum annual handling capacity $C A P_{-} H_{n, y, i}^{S}$, which is only binding in the case of Konrad (8).

$$
\begin{gathered}
\text { level }_{\boldsymbol{y}, \boldsymbol{n}, \boldsymbol{i}}^{S} \leq C A P_{n, y}^{S}+\boldsymbol{b}_{-} \boldsymbol{s i t e}_{\boldsymbol{n} \boldsymbol{i}}^{S} * E X T_{n}^{S} \quad \forall y, n, i \\
\sum_{m} \text { trans }_{\boldsymbol{m}, \boldsymbol{n}, \boldsymbol{y}, \boldsymbol{i}} \leq C A P_{-} H_{n, y, i}^{S} \quad \forall i, n \in k
\end{gathered}
$$

Transport costs are represented as administrative costs, not depending on transported volumes. Therefore, we use the binary variable $\boldsymbol{b}_{-}$trans $\boldsymbol{s}_{\boldsymbol{y}, \boldsymbol{n}, \boldsymbol{m}, \boldsymbol{i}}$ to indicate whether a transshipment between to nodes occurred (10). ${ }^{18}$

$$
\text { trans }_{n, m, y, i} \leq \boldsymbol{b}_{-} \text {trans }_{\boldsymbol{y}, \boldsymbol{n}, \boldsymbol{m}, \boldsymbol{i}} * B I G N \quad \forall y, n, m, i
$$

\subsection{Definition of Scenarios and Cases}

We set up four different cases to evaluate the influence of external restrictions and uncertainties. We focus on the uncertainty about the opening date of Konrad and a potential capacity restriction on the market for dismantling services as detailed in section 2.3. We examine the following cases which are summarized in Table 3:

- Case 1 - Base Case: No restrictions on the market side or uncertainties are considered which is in accordance with other cost assumptions and is inter alia used to compare results with assumptions used by KFK (2016).

- Case 2 - Late Konrad: Considering two scenarios s22 and s32 with Konrad opening either in 2022 or in 2032. Both scenarios are assumed to have equal probability.

\footnotetext{
${ }^{18}$ BIGN is a sufficiently large number to ensure that transport volumes are not constraint once the binary variable is set to one.
} 
- Case 3 - Capacity Restriction: Includes a capacity restriction for dismantling activities. Based on the analysis carried out in Sections 2.3 we assume a maximum dismantling capacity of five reactors in phase II and III.

- Case 4 - Late Konrad + Capacity Restriction: A combination of cases 2 and 3, including the restriction as well as the uncertainty.

Table 3: Overview on assumed restrictions and uncertainties in each case.

\begin{tabular}{lcccccccc}
\hline \hline & & & & \multicolumn{2}{c}{ Dismantling capacity per phase } \\
\hline \hline $\begin{array}{l}\text { Uncertain opening data of } \\
\text { final storage }\end{array}$ & Case 1 & Case 2 & Case 3 & Case 4 & I & II & III & IV \\
Capacity Restriction & \multirow{2}{*}{} & & & $\mathrm{X}$ & $\infty$ & $\infty$ & $\infty$ & $\infty$ \\
\hline \hline
\end{tabular}

\section{Source: Own assumptions.}

\section{Data and Assumptions}

The Decommissioning Status Report contained in the World Nuclear Industry Status Report (Schneider et al. 2018) gives a comprehensive overview of the decommissioning process in Germany, France, UK, USA, Canada, and Japan. More specifically, Thierfeldt and Schartmann (2009), Wealer et al. (2015a), and Kunz et al. (2018) present a comprehensive inventory of the status of dismantling projects of German NPPs, activities on the market for dismantling services and stakeholders of the decommissioning process. As for dismantling costs, the KFK (2016) provides cost data that was the basis for its decision, but figures are only given as aggregate numbers, not adapting guidance of the NEA (2012) on structuring cost estimates by phases. ${ }^{19}$ Generally, there is no comprehensive study publically available that details waste volumes and cost parameters in a sufficiently refined manner to serve as input in our model. Individual parameters were collected in a broad literature research considering scientific papers, reports by regulatory bodies, utilities and contractors.

In the following Table 4 provides a summary on assumed waste volumes and storage capacities, while Table 5 gives an overview on key cost parameters.

Table 4: Parameters - Waste volumes and storage capacities.

\begin{tabular}{l|l|l}
\hline \multicolumn{2}{l}{ Parameter } & \multicolumn{2}{l}{ Value } \\
\hline Waste Volumes & $6,500 \mathrm{~m}^{3}$ & $\begin{array}{l}\text { Volume of packaged waste to be stored in the } \\
\text { finale storage facility Konrad per reactor. }\end{array}$ \\
\hline $\begin{array}{l}\text { ILW and LLW in interim storage } \\
\text { facilities }\end{array}$ & $160,728 \mathrm{~m}^{3}$ & $\begin{array}{l}\text { Total volume of waste packages stored in interim } \\
\text { storage facilities by 2015. }\end{array}$ \\
\hline ILW and LLW from operation & $1,662 \mathrm{~m}^{3}$ & $\begin{array}{l}\text { Volume of packaged waste to be stored in final } \\
\text { storage facility resulting from operation of NPPs } \\
\text { until 2050. }\end{array}$ \\
\hline ILW and LLW from dismantling & $134,250 \mathrm{~m}^{3}$ & $\begin{array}{l}\text { Total volume of waste packages to be stored in } \\
\text { final storage facility resulting from dismantling of } \\
\text { NPPs until 2050. }\end{array}$ \\
\hline Total ILW and LLW & $296,640 \mathrm{~m}^{3}$ & $\begin{array}{l}\text { Total volume of packaged waste to be stored in the } \\
\text { final storage facility Konrad until 2050. }\end{array}$ \\
\hline Storage Capacities & \\
\hline
\end{tabular}

${ }^{19}$ Moreover, KFK (2016) figures only include costs for a subset of all German reactors. Our model includes all reactors as they share the same decommissioning infrastructure. The supplementary material provides a list of all reactor considered in our model. "Commercial rectors" are those also included in KFK (2016) cost estimate. 


\begin{tabular}{l|l|l}
\hline & $220,000 \mathrm{~m}^{3}$ & $\begin{array}{l}\text { We reduce estimate of existing storage capacities } \\
\text { by 30\% compared collected data on facility level. } \\
\text { This considers that space is needed for } \\
\text { unprocessed big components and packaging. }\end{array}$ \\
\hline Final storage capacityd & 303,000 & $\begin{array}{l}\text { Planned capacity of final storage facility Konrad for } \\
\text { ILW and LLW. }\end{array}$ \\
\hline $\begin{array}{l}\text { Annual handling capacity of final } \\
\text { storage }\end{array}$ & $10,000 \mathrm{~m}^{3}$ & $\begin{array}{l}\text { Annual handling capacity is limited by the } \\
\text { transportation capacity in Konrad. }\end{array}$ \\
\hline $\begin{array}{l}\text { a Own assumption based on UM (2015, 17-19); BfS (2015); Köhlmann (2008, 44). } \\
\text { b Own assumptions based on BMUB (2014); UM (2015); Albrecht et al. (2016). } \\
\text { c Detailed description in supplementary material. } \\
\text { d Described by BfS (2015) and Graffunder (2015). }\end{array}$
\end{tabular}

A particular uncertain parameter is the volume of LLW and ILW that needs to be stored from a dismantled NPP. Leaks in pools or tanks are commonly discovered only during the dismantling process and regularly lead to cost overruns in the order of two to five time the original estimate (LaGuardia and Murphy 2012, 14). Consequently, this and other parameters presented in Table 4 and Table 5 are subject to uncertainty. Nevertheless, we compile a comprehensive dataset that serves to break down and assess aggregate cost estimates provided by KFK (2016). We refer to the supplementary material for a more detailed description of the dataset and discussion of parameters.

Table 5: Cost parameters for different process steps of nuclear decommissioning.

\begin{tabular}{|c|c|c|}
\hline Parameter & Value & Comment \\
\hline \multicolumn{3}{|l|}{ Dismantling Costs } \\
\hline Dismantling costs ${ }^{a}$ & 1.08 bnEUR & $\begin{array}{l}\text { Total dismantling costs, assuming a duration of } 17 \\
\text { years. }\end{array}$ \\
\hline Discount rate ${ }^{b}$ & $1 \%$ & $\begin{array}{l}\text { Discount rate assumed for model calculations. In } \\
\text { line with the assumptions of the KFK. }\end{array}$ \\
\hline \multicolumn{3}{|l|}{ Costs by Phase ${ }^{c}$} \\
\hline Post operational phase & 508 mEUR (47\%) & Duration of 5 years. \\
\hline Phase I & 63 mEUR (5.8 \%) & Duration of 3 years. \\
\hline Phase II & 158 mEUR (14.6 \%) & Duration of 4 years. \\
\hline Phase III & 198 mEUR (18.3\%) & Duration of 3 years. \\
\hline Phase IV & 158 mEUR (14.5\%) & Duration of 2 years. \\
\hline \multicolumn{3}{|l|}{ Storage Costs } \\
\hline Yearly storage costs ${ }^{d}$ & 386 EUR per $\mathrm{m}^{3}$ & $\begin{array}{l}\text { Slightly higher cost of } 400 \text { EUR per } \mathrm{m}^{3} \text { costs are } \\
\text { assumed for on-site storage compared to central } \\
\text { storage facilities accounting for economies of } \\
\text { scale. }\end{array}$ \\
\hline $\begin{array}{l}\text { Interim storage } \\
\text { investment cost }^{\mathrm{e}}\end{array}$ & 25,000 EUR per $\mathrm{m}^{3}$ & \\
\hline Container costs ${ }^{f}$ & 7000 EUR per $\mathrm{m}^{3}$ & $\begin{array}{l}\text { Costs for container units suitable for storage at the } \\
\text { final storage facility Konrad. }\end{array}$ \\
\hline Transportation costs ${ }^{g}$ & $\begin{array}{l}0.15 \text { mEUR per } \\
\text { transport }\end{array}$ & $\begin{array}{l}\text { Transportation costs for LLW and ILW mainly } \\
\text { comprise fixed costs that do not depend on the } \\
\text { transported volumes. }\end{array}$ \\
\hline \multicolumn{3}{|c|}{$\begin{array}{l}\text { b An overview on different interest rate scenarios and their impact on the overall decommissioning liabilities is } \\
\text { given by Wieland-Böse and Jonas (2015a). The interest rate has a significant impact on cost estimate and is } \\
\text { frequently criticized to underestimate the costs of the decommissioning process (Hirschhausen, Gerbaulet, } \\
\text { Kemfert, Reitz, Schäfer, et al. 2015, 1080). }\end{array}$} \\
\hline \multicolumn{3}{|c|}{$\begin{array}{l}{ }^{c} \text { Distribution of costs based on Leidinger }(2015,17) \text {. Costs for the post operational phase from swissnuclear } \\
\text { (2011). Duration based on Wealer et al. }(2018 a, 144-45) .\end{array}$} \\
\hline \multicolumn{3}{|c|}{$\begin{array}{l}\text { d Own estimate using occupation of storages operated by GNS and associated turnover for warehouse } \\
\text { services in } 2014 \text { (GNS 2015). }\end{array}$} \\
\hline
\end{tabular}


e Own calculation based on cost estimate of 10 mEUR per facility and an average size of $4000 \mathrm{~m}^{3}$ (Knack 2012, fol. 27; Albrecht et al. 2016).

${ }^{f}$ Own assumption using overall estimates by Knack (2012, fols. 26-27) as reference.

g Own calculation based on container cost for Swiss NPP KKB Beznau (swissnuclear 2011, 29-30). Average mass estimate for conversion to volume taken from Siempelkamp (2015, fol. 17).

\section{Numerical Results}

The model output comprises the assigned dismantling schedule for each reactor, resulting waste volumes and waste transports as well as the amount and temporal distribution of associated costs. It allows tracking flows and storage level of LLW and ILW and investment in additional on-site storage facilities. The model results assess the optimal decommissioning process and associated cost in the Base Case. Additional cases are considering the realization of two specific risks, namely, deferred availability of final storage and limited dismantling capacity, as well as interdependencies between these two. Detailed model results can be found in the supplementary material.

In general, results clearly indicate that overall costs are mainly driven by the dismantling costs independent from the considered case (Table 6). As pointed out in section 5, these costs are themselves subject to uncertainties. Transportation costs play an insignificant role for this analysis. Investment costs in additional storage facilities are also rather small with a maximum of $0.37 \mathrm{bn}$ EUR, when a deferred opening of Konrad is assumed (Case 2). The low costs for the storage extension is due to the high volume of storage capacity which is assumed to be available in centralized storage facilities (especially in central storage Nord (ZLN)). Variable storage cost for LLW and ILW (Discounted storage costs in Table 6), on the other hand, are a significant position. They contribute $11 \%$ to $14 \%$ to total decommissioning cost. Even though total cost increases between the Base Case and Cases 2-4 seem relatively low, compared to a total amount of 21.92 bnEUR, it has to be noted that the dismantling costs themselves cannot be reduced by changes in the logistical process.

Table 6: Overview of cost results by category for the different cases, in bn EUR $\mathbf{R}_{\mathbf{2 0 1 6}}$.

\begin{tabular}{|c|c|c|c|c|}
\hline Overview $^{a}$ & $\begin{array}{c}\text { Base } \\
\text { Case (1) }\end{array}$ & $\begin{array}{c}\text { Late } \\
\text { Konrad (2) }\end{array}$ & $\begin{array}{c}\text { Capacity } \\
\text { restriction (3) }\end{array}$ & $\begin{array}{c}\text { Late Konrad + } \\
\text { Capacity } \\
\text { Restriction (4) }\end{array}$ \\
\hline Discounted dismantling cost ${ }^{\mathrm{b}}$ & 19.38 & 19.38 & 19.96 & 19.95 \\
\hline $\begin{array}{l}\text { Discounted dismantling cost } \\
\text { "commercial reactors" onlyc }\end{array}$ & 17.37 & 17.37 & 17.91 & 17.91 \\
\hline Discounted transportation cost & 0.03 & 0.02 & 0.02 & 0.02 \\
\hline Discounted storage cost & 2.46 & 3.17 & 2.42 & 3.13 \\
\hline Storage extension cost & 0.05 & 0.37 & 0.05 & 0.33 \\
\hline Total discounted cost & 21.92 & 22.94 & 22.45 & 23.43 \\
\hline \multicolumn{5}{|c|}{$\begin{array}{l}\text { a Operating and closing costs for Konrad are not endogenously considered within the model. These costs are } \\
\text { specified by BMUB (2015) to be } 81.6 \mathrm{~m} \text { EUR } \text { R }_{2012} \text { for each operating year and an additional amount of } 290 \mathrm{~m} \\
\text { EUR } 2012 \text { for the closure of Konrad. Considering an operating duration of } 30 \text { years, the total costs add up to } \\
2.87 \text { bn EUR } 2016 \text {. } \\
\text { b Dismantling cost include packaging and container costs. }\end{array}$} \\
\hline
\end{tabular}

The Base Case allows us to compare model results against assumption taken as a basis for the German nuclear consensus (Gesetzespaket zur "Neuordnung der Verantwortung in der kerntechnischen Entsorgung“, German Parliament 2016b). Figure 5 and Table 7 compare calculated dismantling and transportation cost for commercial reactors with yearly costs reported by Warth\&Klein (Wieland-Böse and 
Jonas 2015a). Calculated costs for the decommissioning for the commercial reactors in our study are in line assumptions stated as basis for the nuclear consensus. Discounted dismantling cost for commercial reactors are 0.84 bn EUR lower than the available funds for the utilities, assuming costs of 1.08 bnEUR for the dismantling of a NPP in our calculations (see Table 7).

Table 7: Comparison of results obtained from Base Case with other sources.

\begin{tabular}{|c|c|c|c|}
\hline Overview & Base Case (1) & Reference & Source \\
\hline Total NPV & & & \\
\hline $\begin{array}{l}\text { Discounted dismantling } \\
\text { cost "commercial reactors" } \\
\text { onlya }\end{array}$ & $\begin{array}{l}16.48 \text { bn } \\
\text { EUR }_{2016}\end{array}$ & 17.32 bn EUR $2016^{b}$ & $\begin{array}{l}\text { Wieland-Böse and } \\
\text { Jonas }(2015 a, 13)\end{array}$ \\
\hline $\begin{array}{l}\text { Discounted storage and } \\
\text { transport cost }\end{array}$ & $\begin{array}{l}2.54 \mathrm{bn} \\
\text { EUR }_{2016}\end{array}$ & $\begin{array}{l}\text { No clear differentiation } \\
\text { between cost associated with } \\
\text { HLW and ILW/LLW }\end{array}$ & \\
\hline
\end{tabular}

1400

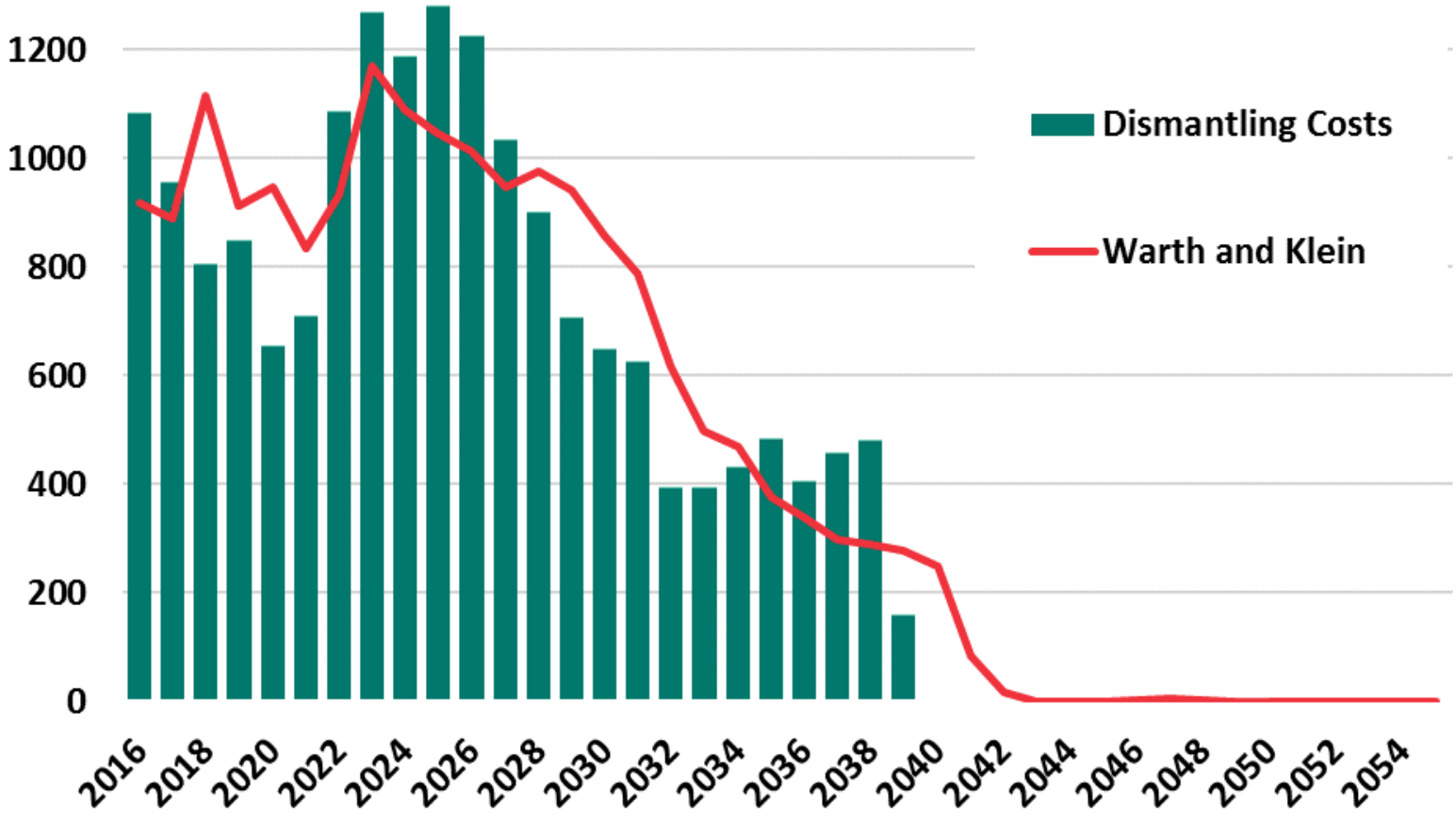

Figure 5: Annual dismantling cost for commercial reactors in million EUR, comparison of model results to KFK underlying study.

Figure 6 shows the development of storage levels in the Base Case. By 2022, a maximum of $188.000 \mathrm{~m}^{3}$ of ILW and LLW is stored in intermediate on-side and central storage facilities. After Konrad starts to operate in 2022 it takes 30 years until all inventories are transferred to the final storage facility. 


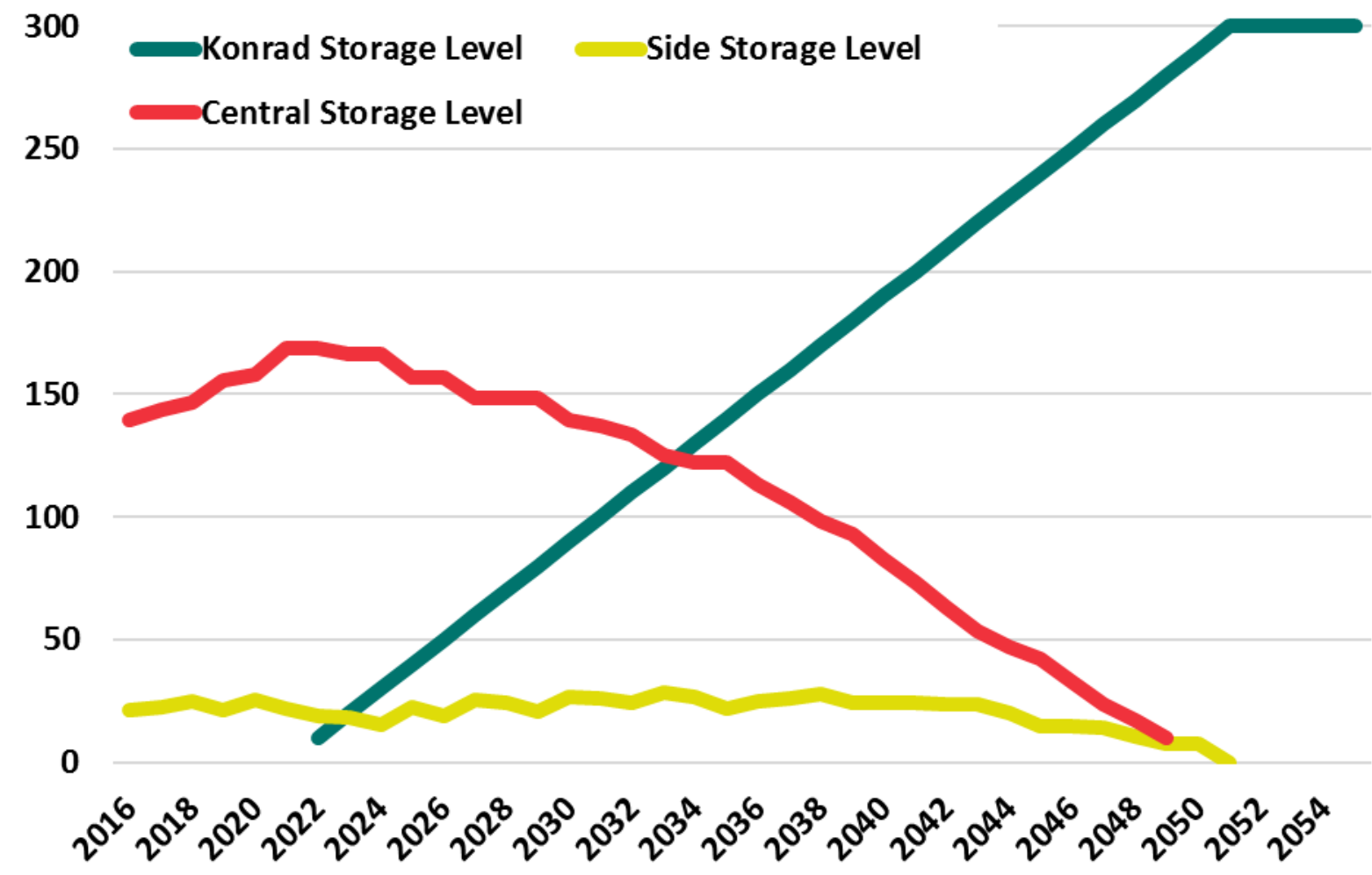

Figure 6: Storage Levels in the Base Case in thousand $\mathbf{m}^{3}$.

The other cases consider realization of different risks and the scheduling of dismantling activities under this uncertainty.

\section{$\underline{\text { Late availability of Konrad }}$}

By introducing uncertainty about the timely availability of Konrad in Case 2, the total expected cost rise by 1.03 bnEUR compared to Case 1. $0.72 \mathrm{bnEUR}$ of these costs account for variable storage costs while the remaining 0.32bnEUR are used for investments in intermediate storage facilities. The optimal scheduling of dismantling activities under uncertainty about the opening date of Konrad is not changed compared to the Base Case. Expected additional storage costs do not warrant the need to slow the dismantling process by adding waiting periods. See supplementary material for details on the phasing of the decommissioning of the individual nuclear power plants.

\section{Limited dismantling capacity}

In the Base Case a total of nine reactors are in the dismantling phase II by 2022 . When introducing a capacity restriction for the dismantling phases to a maximum of five reactors for phase II and phase III in Case 3, total costs increase by $0.49 \mathrm{bn}$ EUR. The dismantling costs rise due to nine of 27 reactors needing additional waiting periods between the decommissioning phases (see Figure 7). At the same time, the average time LLW and ILW spent in intermediate storage facilities is reduced, leading to a small cost decrease of 0.04bnEUR compared to the Base Case. Investments in intermediate storage facilities are not reduced. The total increase is lower than in Case 2. The completion of dismantling activities is postponed by two years to 2042 compared to the Base Case. 


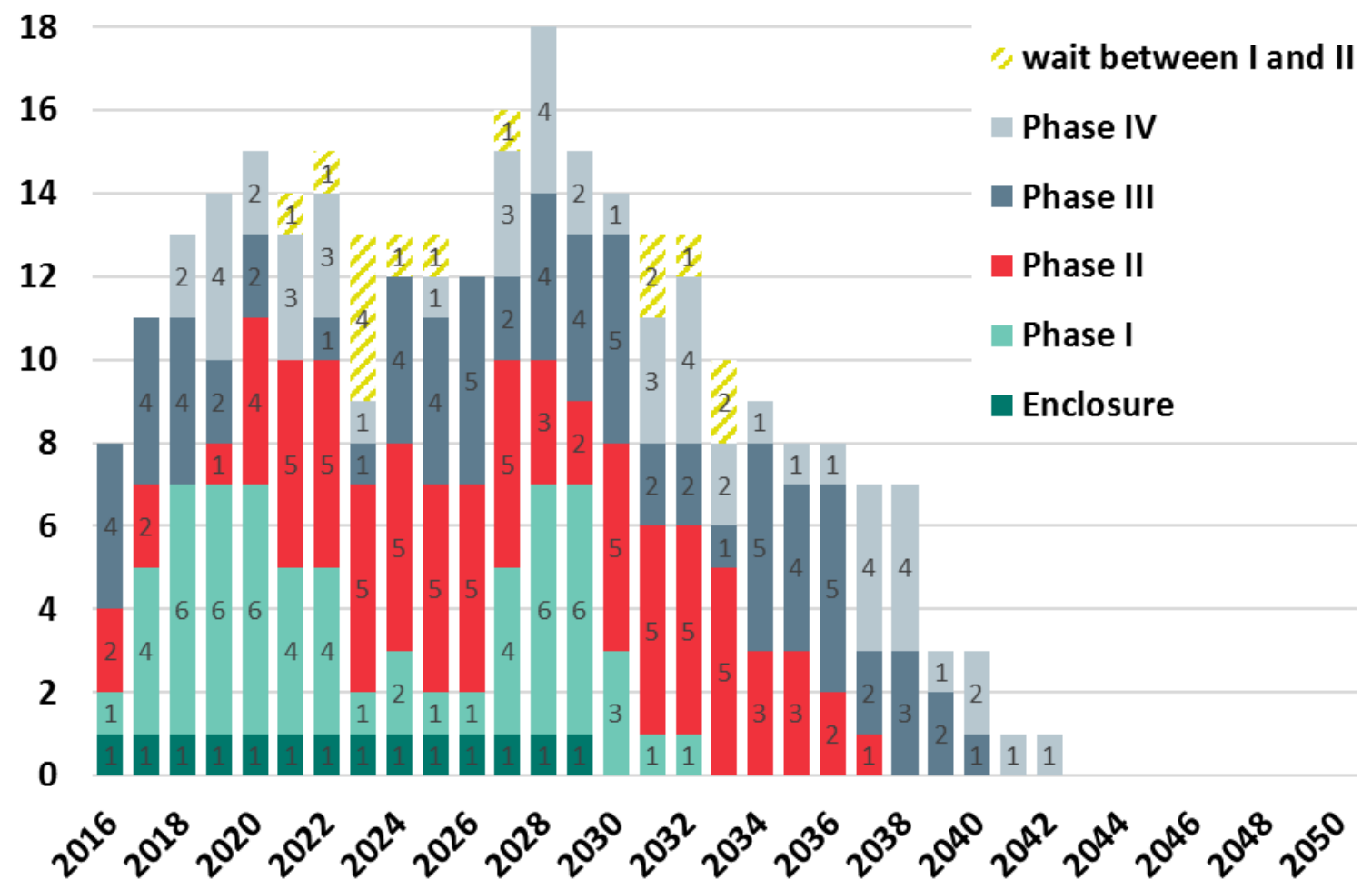

Figure 7: Reactors by phase in Case 3 - Capacity Restriction.

\section{Late Konrad and Limited Dismantling Capacities}

The combined effect of considering uncertainty about the opening date of Konrad and limited dismantling capacities leads to a total cost increase of 1.51 bnEUR. While dismantling cost increase only by $3 \%$ transportation and intermediate storage cost increase by $37 \%$. The total cost increase mostly corresponds to the combined effects from Case 1 and 2. This indicates that the effects are additional and exhibit low interdependency.

\section{Conclusions and Policy Implications}

Following the Fukushima Daiichi accident, the German government reconfirmed the early phase-out of nuclear power that was originally legislated in 2002 but revoked in 2009. As a reaction to the accident, the operating license from eight reactors was revoked immediately. The remaining seven reactors still connected to the grid in 2018 are gradually phasing-out until 2023. Another seven reactors have already been shut down before 2011. Every single one of these 23 reactors - located on 17 sites - must be decommissioned in the upcoming decades.

The decommissioning process is a multidisciplinary task that involves technical, regulatory, and organizational activities. The process has high potentials for economies of scale and a need for integrated planning to tackle the complex task of investment in equipment and operation of a logistical network under uncertainty. Stakeholders are following different incentives while they hold control over critical parts of the process. 
We address the basic need to evaluate the resulting dismantling activities, waste flows and storage levels as well as the associated costs and potential bottlenecks. To this end, we set up a two-stage stochastic optimization model. We make use of our quantitative modeling framework to back-up the qualitative arguments that assess the new institutional arrangement for the nuclear decommissioning process induced by the new regulation in Germany and discuss intended and unintended incentives.

One particular concern of public interest in nuclear decommissioning is, that utilities may go out of business without leaving sufficient funds set aside in an independent fund to finance the full decommissioning process. In Germany, costs, financial provisions, and risks of the decommissioning process came back into focus in 2014, driven by the German Nuclear Phase-out and the dire financial situation of the major energy utilities. As a reaction to these concerns and the evolving public debate, the German government installed a commission that was charged with reviewing the funding for the nuclear phase-out ("Kommission zur Überprüfung der Finanzierung des Kernausstiegs (KFK)), in October 2015. The KFK suggested a Reform of Liability in Nuclear Waste Disposal. A central piece of the new regulation are redistributed financial liabilities and responsibilities where utilities were now allowed to transfer the risk associated with the interim and final storage of nuclear waste to the public.

This paper assesses whether the new regulation will ultimately be to the benefit of the public. In particular, we look (1) at the new split of responsibility and liabilities between dismantling and packaging, transport, and interim and final storage, (2) leaving direct dismantling as the only option, (3) whether sufficient funds have been assigned for nuclear dismantling, and (4) highlight structural deficits in costs estimates for nuclear decommissioning.

(1) While formerly utilities were responsible for the entire decommissioning chain, with the new regulation, the responsibility and associated risks for the storage of nuclear waste are transferred to a government body. In theory, utilities now have the incentive to start the direct dismantling of their reactors immediately, as they are freed from risks associated with the timely availability of a waste final storage. Model results indicate that uncertainty about the availability of Konrad does not change the optimal dismantling schedule. In other words, the uncertainty about Konrad does not warrant any delay in the dismantling activities. By breaking the chain between dismantling and storage, utilities are not affected by downstream costs anymore. Consequently, now the public must bear the costs of lacking coordination between the dismantling schedule of the reactors and the availability of a final storage site. The delay of Konrad adds more than 1bnEUR (over 20\%) in storage costs to be borne by a public fund now responsible for the intermediate storage. Although, a delay was already foreseen by many scholars and experts before the re-organization of funds, these costs were not accounted for when funds were transferred.

(2) Moreover, the prescribed schedule of the German nuclear phase-out with immediate dismantling as the only option. While one of the rationales is to ensure the availability of skilled workers and site-specific knowledge, which would be gone, if dismantling would be postponed; this decision leads to a very dense schedule of dismantling activities. In our Base Case, a total of nine reactors are in the technical demanding dismantling phase II at the same time. This phase required highly specialized equipment which is rarely available neither in Germany nor elsewhere. If the prescribed schedule is to be realized limited capacity in equipment and know-how could lead to costly delays 
in the dismantling process. Model results show that limiting dismantling capacity in the critical phases II and III increase dismantling costs for commercial reactors from 17.37 bnEUR to 17.91 bnEUR. It is questionable whether this risk is sufficiently addressed or understood by operators and mirrored in their current provisions. Based on an extensive monitoring of decommissioning activities in Germany, Wealer et al. (2015) argue that further delays are very likely and yet unaddressed.

(3) The motivation to formulate a model to assess costs and dynamics was also to better understand cost estimates. Available cost estimates from technical reports and from documents supporting the policy process only provide aggregated values. With our calculations we provide a detailed breakdown of dismantling activities, uncertainties and associated cost for comparison. Even though cost estimates used in this paper are themselves subject to uncertainty we would like to offer some possible reasons for the deviation between model results and the study by Warth\&Klein which is used as a basis for the German Nuclear Consensus (Wieland-Böse and Jonas 2015a; KFK 2016). Using rather high cost estimates from the literature, in our Base Case we calculate a net present value of dismantling cost for commercial reactors that is 0.89 bnEUR below estimates used as a basis for the nuclear consensus. This could have two reasons: (1) Either additional risks are considered, e.g. risk of delay in decommissioning or (2) companies had an incentive to state high cost at this point, in anticipation of the distribution of funds later proposed in the nuclear consensus. This allows to shift some portion of the available funds towards dismantling, an activity which remains in their domain also after the consensus.

(4) On a more general note, utilities and existing cost estimates might simply underestimate the cost of dismantling. Assessing whether provisions for decommissioning are sufficient, critically hinges on the a-prior assessability of future costs. Though current cost estimates are claimed to be updated annually, the underlying calculations are questionable as they are not based on past experience but use generic engineering estimates which proved to be bad proxies for the real associated costs (Wealer et al. 2017). In this context, looking at completed and ongoing decommissioning processes (e.g. in France, UK), one can see that all projects exhibit significant cost overruns as well as delays which results from heavily underestimating the technological complexity of the decommissioning process (see Schneider et al. 2018). In 2018, we observe that only one of the eight reactors shut down in 2011 has been defueled, and none of them has actually started the decommissioning process. With the post-operational phase being the most expensive stage of the decommissioning process (more than $50 \%$ of total dismantling costs), this is a good indication that cost overruns can also be expected for these and other reactors. Given the persistent dire situation of the German utilities, further cost increases might render the agreed assignment of funds unappropriated to ensure a fast and safe decommissioning process.

In a nutshell, it is questionable whether the new regulation will ultimately be to the benefit of the public: While unbundling dismantling activities from storage risk is one of the major goals of the new regulation, we find that in fact there is not much interdependency. Due to comparably low interim storage costs, the optimal dismantling schedule is not affected by the availability of a final storage site. Still, the public will now bear the costs of delays in completion of the final storage, which have been likely already before the re-organization of funds, but not accounted for when funds were transferred. Taking into account the lack 
of site-specific cost estimate and frequent cost overruns the agreed assignment of funds is unappropriated to ensure a fast and safe decommissioning process. Given this dark outlook, other organization models for the decommissioning process should be considered that also take into account potential market concentration in the market for dismantling services (Jänsch et al. 2017; Kunz et al. 2018).

With the new law, regulations on the waste delivered to the interim storage sites will be the crucial element of interaction between the private utilities and the public storage provider. Future research could therefore focus on the assessment of this interface to ensure, a safe and efficient packaging and interim storage. This becomes even more of an issue, if additional amounts of waste of $275,000 \mathrm{~m}^{3}$ resulting from the retrieval of waste stored in the final storage facility Asse II, and Uranium, that have to be treated and stored in interim and a final storage facility (BfS 2014b; BMUB 2014), is also taken into account.

Not least due to an aging international nuclear fleet, the problems that are now faced in Germany will increasingly become an issue in other countries, as well. For now, the lessons learned from the upcoming large-scale decommissioning carried out in Germany are definitely not the next "Wende" that is exported from Germany to serve as a role model around the world.

\section{References}

Agneb (Swiss). 2015. "Auswirkungen einer verlängerten Abklinglagerung auf die radioaktiven Abfälle." Schweizer Arbeitsgruppe des Bundes für die nukleare Entsorgung, Untergruppe «Abklinglager». https://www.bag.admin.ch/dam/bag/de/dokumente/str/fanm/radioaktive-materialenabfaelle/agneb-auswirkungen-verlaengerten-abklinglagerung-radioaktiv.pdf.download.pdf/agnebauswirkungen-verlaengerten-abklinglagerung-radioaktiv.pdf.

Albrecht, Christina, Claudia Baitinger, Thorben Klages, Jutta Beckmann, Peter Dickel, Dieter Kaufmann, and Lothar Krause. 2016. "Atommüllreport Daten." Atommüllreport. 2016. http://www.atommuellreport.de/daten.html.

Arbeitsgemeinschaft Schacht KONRAD e.V. 2015. "Stellungnahme Und Einwendungen Zum Entwurf Des Nationalen Entsorgungsprogramms Vom 6. Januar 2015." Arbeitsgemeinschaft Schacht KONRAD

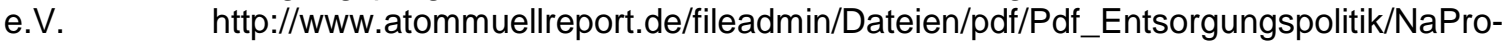
Stellungnahme_Arbeitsgemeinschaft_Schacht_Konrad.pdf.

AREVA. 2017. "AREVA-EWN Consortium to Dismantle the Reactor Pressure Vessel Internals of the Brunsbüttel Nuclear Power Plant," June 9, 2017. http://www.sa.areva.com/EN/news10956/arevaewn-consortium-to-dismantle-the-reactor-pressure-vessel-internals-of-the-brunsbttelnuclear-power-plant.html.

AtG. 2015. 13 Novelle of the Atomgesetz. https://www.gesetze-im-internet.de/bundesrecht/atg/gesamt.pdf.

Atomforum. 2013. "Atomforum 2013 Rückbau von Kernkraftwerken." DAtF.

Bacmeister, George U. 2009. "Waste Management Concept during Dismantling of the Nuclear Power Plant Stade in Germany." presented at the TÜV Symposium Wiesbaden, September 22. http://www.tuevnord.de/cps/rde/xbcr/tng_de/Bacmeister-

Waste_Management_Concept_during_Dismantling_of_the_Nuclear_Power_Plant_Stade_in_Ger many.pdf.

Bartels, Jan-Hendrik, Thorsten Gather, and Jürgen Zimmermann. 2011. "Dismantling of Nuclear Power Plants at Optimal NPV." Annals of Operations Research 186 (1): 407-27. https://doi.org/10.1007/s10479-010-0788-9.

Bechtel. Press release. 2017. "Bechtel, GE Hitachi Nuclear Energy Join Forces to Pursue Nuclear Plant Decommissioning," March 22, 2017. https://www.bechtel.com/newsroom/releases/2017/03/bechtel-ge-hitachi-nuclear-energy/.

BfS. 2016b. "Geplante Einlagerung." Www.Endlager-Konrad.De. 2016b. http://www.endlagerkonrad.de/Konrad/DE/themen/einlagerung/einlagerung/einlagerung_node.html. 
2009. "Leifaden zur Stillegung, zum sicheren Einschluss und zum Abbau von Anlagen oder Anlagenteilen nach $\S 7$ des Atomgesetzes." In Handbuch Reaktorsicherheit. RS III 4-17031-3/6.1. Bonn: BfS. http://www.bfs.de/SharedDocs/Downloads/BfS/DE/rsh/3-bmub/3_73_1109.pdf?_.

2014a. "State and Development of Nuclear Energy Utilization in the Federal Republic of Germany." https://doris.bfs.de/jspui/handle/urn:nbn:de:0221-2014102711847.

2014b. "Asse II mine, Report on the planning of retrieval, January 2014." BfS-25/14. Salzgitter: Federal Office for Radiation Protection. https://doris.bfs.de/jspui/handle/urn:nbn:de:02212014021211169.

2015. "Reststoff- Und Abfallmanagement Bei Der Stillegung." September 9, 2015. http://www.bfs.de/DE/themen/kt/stilllegung/abfallmanagement/abfallmanagement_node.html.

2016. "Dauer Des Umbaus von Schacht Konrad Zu Einem Endlager." Www.Endlager-Konrad.De. 2016.

http://www.endlager-

konrad.de/Konrad/DE/themen/umbau/umbaudauer/Umbaudauer.html;jsessionid=1AFE4A9231C3 054490A0A99B012887C5.1 cid371.

BGE. 2017. "Gutachten Zur Ermittlung Der Terminlage Für Das Lau Fende Projekt Endlager Konrad Durch Den TÜV Rheinland." https://www.bge.de/fileadmin/user_upload/Konrad/Dokumente/Gutachten_Ermittlung_Terminlage _Projekt_Konrad_TUEV_Rheinland_komplett_20171117.pdf.

Birge, John R., and François Louveaux. 2011. Introduction to Stochastic Programming. Seconde. Springer Series in Operation Research and Financiel Engineering.

BMUB. 2014. "Verzeichnis Radioaktiver Abfälle: Bestand Zum 31. Dezember 2013 Und Prognose." K-MAT 13. http://www.bundestag.de/blob/337852/7c57c8dc16bfc64f8ae86006964be6b2/kmat _13data.pdf Retrieved.

2015. "Report on the Cost and Financing of Disposal of Spent Fuel and Radioactive Waste." http://www.bmub.bund.de/fileadmin/Daten_BMU/Download_PDF/Nukleare_Sicherheit/abfallentso rgung_kosten_finanzierung_bf.pdf.

BMWI. 2017. "Kernkraftwerksbetreiber Haben Einzahlungen an Nuklearen Entsorgungsfonds in Höhe von Rd. 24 Milliarden Euro Geleistet." Press Release. 072017. https://www.bmwi.de/Redaktion/DE/Pressemitteilungen/2017/20170703-kernkraftsbetreiberhaben-einzahlungen-an-nuklearen-entsorgungsfonds-in-hoehe-von-24-mrd-euro-geleistet.html.

Bradbury, D. 1992. "Decommissioning of Civil Nuclear Facilities: A World Review." Energy Policy, The first 50 years of nuclear power: legacy and lessons - Part 2, 20 (8): 755-60. https://doi.org/10.1016/0301-4215(92)90036-2.

Brammer, Klaus-Jürgen, and Erich Gerhards. 2015. "Commissioning Time for the Repository Konrad Consequences for the Decommissioning." presented at the ICON, November 18.

Coelho, Leandro C., Jean-François Cordeau, and Gilbert Laporte. 2012. "The Inventory-Routing Problem with Transshipment." Computers \& Operations Research 39 (11): 2537-48. https://doi.org/10.1016/j.cor.2011.12.020.

EC. 2014. Richtlinie 2013/59/Euratom des Rates vom 5. Dezember 2013 zur Festlegung grundlegender Sicherheitsnormen für den Schutz vor den Gefahren einer Exposition gegenüber ionisierender Strahlung und zur Aufhebung der Richtlinien 89/618/Euratom, 90/641/Euratom, 96/29/Euratom, 97/43/Euratom und 2003/122/Euratom. 013. Vol. OJ L. http://data.europa.eu/eli/dir/2013/59/oj/deu.

EON. 2008. "Stade: Stilllegung und Rückbau des Kernkraftwerks - vom Kernkraftwerk zur „Grünen Wiese"." EKK 03/2008. Hannover. https://www.eon.com/content/dam/eon-contentpool/eon/company-asset-finder/asset-profiles/stade-power-plant/kernkraftrueckbau_Stade_de.pdf.

ESK. 2014. "Vergleich Der Massenströme Bei Der Stillegung von Kernkraftwerken in Deutschland Und Frankreich."

Entsorgunskommission. http://www.entsorgungskommission.de/sites/default/files/reports/vergleichmassenstroeme_home page.pdf.

FÖS. 2012. "Rückstellungen für Stillegung/Rückbau und Entsorgung im Atombereich: Thesen und Empfehlungen zu Reformoptionen." http://www.foes.de/pdf/2012-FOES-RueckstellungenAtom.pdf. 
Frauenhofer ISE. 2018. "Electricity Generation in Germany in 2018." Energy Charts. June 16, 2018. https://www.energy-charts.de/energy_pie.htm\#.

Fritz, Peter, and Bruno Kuckartz. 2015. "Current Status of the Decommissioning Projects in Germany." presented at the ICOND, Bonn, November 17.

German Office of Radiation Protection. 2016. Verordnung Über Den Schutz Vor Schäden Durch lonisierende Strahlen (Strahlenschutzverordnung - StrlSchV). RS -Handbuch. Vol. 1A-8. https://www.bfs.de/SharedDocs/Downloads/BfS/DE/rsh/1a-atomrecht/1A-8-

StrlSchV.pdf?_blob=publicationFile \&v=8.

German Parliament. 2010. Gesetzentwurf der Fraktionen der CDU/CSU und FDP: Entwurf eines Elften Gesetzes zur Änderung des Atomgesetzes. http://dip21.bundestag.de/dip21/btd/17/030/1703051.pdf.

2016a. "Endlager - Kompromiss Noch Ergänzt." Deutscher Bundestag, Pik 2 Parlamentsnachrichten. December 14, 2016. https://www.bundestag.de/presse/hib/2016_12/1484960.

2016b. Gesetz Zur Neuordnung Der Verantwortung in Der Kerntechnischen Entsorgung. 18/10671. Vol. 768/16.

- 2017. Entsorgungsfondsgesetz - EntsorgFondsG. https://www.gesetze-iminternet.de/entsorgfondsg/BJNR011410017.html.

Ghiani, G., D. Laganà, E. Manni, R. Musmanno, and D. Vigo. 2014. "Operations Research in Solid Waste Management: A Survey of Strategic and Tactical Issues." Computers \& Operations Research 44 (April): 22-32. https://doi.org/10.1016/j.cor.2013.10.006.

GNS. 2015. "Jahresabschluss zum Geschäftsjahr vom 01.01.2014 bis zum 31.12.2014." Essen: Gesellschaft für Nuklear-Service mbH. https://www.bundesanzeiger.de/ebanzwww/wexsservlet.

Graffunder, Iris. 2015. "Waste Management for the Repository Konrad." presented at the ICON.

Hawickhorst, Wolfgang. 1997. "Management of Radioactive Wastes from the Operation of Nuclear Power Plants." Nuclear Engineering and Design 176 (1-2): 171-76. https://doi.org/10.1016/S00295493(96)01353-2.

Hirschhausen, Christian, Clemens Gerbaulet, Claudia Kemfert, Felix Reitz, and Cornelia Ziehm. 2015. "Atomausstieg Geht in Die Nächste Phase: Stromversorgung Bleibt Sicher-Grols Se Herausforderungen Und Hohe Kosten Bei Rückbau Und Endlagerung." DIW-Wochenbericht 82 (22): 523-531.

Hirschhausen, Christian von, Clemens Gerbaulet, Claudia Kemfert, Felix Reitz, Dorothea Schäfer, and Cornelia Ziehm. 2015. "Rückbau Und Entsorgung in Der Deutschen Atomwirtschaft: ÖffentlichRechtlicher Atomfonds Erforderlich." DIW-Wochenbericht 82 (45): 1072-1082.

Hwang, Y.S., C.H. Kang, S.G. Kim, and H.S. Park. 2003. "Progress of Radioactive Waste Management in Korea." Progress in Nuclear Energy 42 (2): 159-77. https://doi.org/10.1016/S0149-1970(03)800070.

IAEA. 2002. Decommissioning Costs of WWER-440 Nuclear Power Plants: Interim Report : Data Collection and Preliminary Evaluations. Vienna: International Atomic Energy Agency. http://wwwpub.iaea.org/MTCD/publications/PDF/te_1322_web.pdf.

2007. "IAEA Safety Glosarry: Terminology Used in Nuclear Safety and Radiation Protection." Vienna, Austria: International Atomic Energy Agency (IAEA). http://wwwns.iaea.org/standards/safety-glossary.asp.

2018. "Operational and Long-Term Shutdown Reactors." PRIS Power Reactor Information System. June 15, 2018. https://www.iaea.org/PRIS/WorldStatistics/OperationalReactorsByCountry.aspx.

IAEE. 1991. Nuclear Decommissioning Economics. Vol. Special Issue. Vol. 12. Energy Journal.

Jänsch, Elisabeth, Achim Brunnengräber, Christian von Hirschhausen, and Christian Möckel. 2017. "Wer soll die Zeche zahlen? Diskussion alternativer Organisationsmodelle zur Finanzierung von Rückbau und Endlagerung." GAIA, Jahrhundertprojekt Endlagerung, 26 (2): 118-20.

KFK. 2016. "Verwantwortung und Sicherheit - Ein neuer Entsorgungskonses: Abschlussbreicht der Komission zur Überprüfung der Finanzierung des Kernenergieausstiegs." Berlin: Kommission zur $\begin{array}{lllll}\text { Überprüfung der } & \text { Finanzierung } & \text { Kernenergieausstiegs. }\end{array}$ 
http://www.bmwi.de/BMWi/Redaktion/PDF/B/bericht-der-expertenkommission-

kernenergie, property=pdf, bereich=bmwi2012, sprache=de,rwb=true. pdf.

Klasen, Jörg, and Seizer Burkhard. 2015a. "Managing Complexity of Nuclear Decommissioning \& Dismantling Projects - An Advanced Project- Management Approach." presented at the ICOND, Bonn, November 18.

2015b. "Managing Complexity of Nuclear Decommissioning \& Dismantling Projects - An Advanced Project- Management Approach." presented at the ICOND, Bonn, November 18.

Knack, M. 2012. "Decommissioning - Three Main Strategies: Immediate Dismantling, Safe Enclosure (Deferred Dismantling), Entombment." presented at the IAEA RER/9/120 Workshop on planning and licensing of decommissioning projects, November 26. https://www.iaea.org/OurWork/ST/NE/NEFW/WTS-

Networks/IDN/idnfiles/WkpPlanLicencingDecomProjetc_Germany2012/WkpPlanLicencingDecom Projetc_Germany2012-Decommissioning_Strategies-Knaack.pdf.

Köhlmann, Sarah. 2008. Die Abbildung von nuklearen Entsorgungsverpflichtungen in IFRS-Abschlüssen: eine Analyse der Bilanzierung, Offenlegung und Prüfung. 1. Aufl. Gabler Edition Wissenschaft. Wiesbaden: Gabler.

Küchler, Swantje, Bettina Meyer, and Rupert Wronski. 2014. "Atomrückstellungen für Stilllegung, Rückbau und Entsorgung." Berlin: BUND. http://foes.de/pdf/2014-09-FOES-StudieAtomrueckstellungen.pdf.

Kunz, Friedrich, Felix Reitz, Christian von Hirschhausen, and Ben Wealer. 2018. "Nuclear Power: Effects of Plant Closures on Electricity Markets and Remaining Challenges." In Energiewende "Made in Germany" Electricity Sector Reform in the European Context, edited by Christian von Hirschhausen, Clemens Gerbaulet, Claudia Kemfert, Casimir Lorenz, and Pao-Yu Oei. Berlin, Germany: Springer International Publishing AG.

Kunze, V. 2013. "The Construction of the Konrad Repository-Status and Perspective-13034." In . WM Symposia, 1628 E. Southern Avenue, Suite 9-332, Tempe, AZ 85282 (United States). http://www.wmsym.org/archives/2013/papers/13034.pdf.

LaGuardia, T. S., and K. C. Murphy. 2012. "4 - Financing and Economics of Nuclear Facility Decommissioning." In Nuclear Decommissioning, edited by Michele Laraia, 49-86. Woodhead Publishing Series in Energy. Woodhead Publishing. https://doi.org/10.1533/9780857095336.1.49.

Laraia, Michele, ed. 2012. Nuclear Decommissioning: Planning, Execution and International Experience. Woodhead Publishing Series in Energy 362. Oxford: Woodhead.

Lee, William, Michael Ojovan, and Carol Jantzen, eds. 2013. Radioactive Waste Management and Contaminated Site Clean-up: Processes, Technologies and International Experience. Woodhead Publishing Series in Energy, no. 48. Philadelphia, PA: Woodhead Pub.

Leidinger, Bernhard. 2015. "Cost Management during Decommissioning: What Are the Cost-Drivers." presented at the ICOND, Bonn, November 17.

Lough, W. Timothy, and K. Preston White. 1990. "A Critical Review of Nuclear Power Plant Decommissioning Planning Studies." Energy Policy 18 (5): 471-79. https://doi.org/10.1016/03014215(90)90048-9.

Lower Saxony, Ministry for Environment, Energy, and Climate Protection. 2014. "Ereignisinformation Zum Kernkraftwerk Stade (KKS) | Nds. Ministerium Für Umwelt, Energie Und Klimaschutz." January 28, 2014. http://www.umwelt.niedersachsen.de/kernkraftwerk_stade/ereignisinformation-zumkernkraftwerk-stade-kks-129862.html.

NEA. 2012. "International Structure for Decommissioning Costing (ISDC) of Nuclear Installations." Paris, France: Organisation for Economic Co-operation and Development (OECD). www.oecdnea.org/rwm/reports/2012/ISDC-nuclear-installations.pdf.

2016. "Costs of Decommissioning Nuclear Power Plants." Nuclear Development. Paris, France: Organisation for Economic Co-operation and Development (OECD).

PNNL. 2012. "Assessment of the Adequacy of the 10 CFR 50.75(c) Minimum Decommissioning Fund Formula." NRC Job Code J-4275. Washington, D.C., USA: Office of Nuclear Reactor Regulation U.S. Nuclear Regulatory Commission. https://www.nrc.gov/docs/ML1306/ML13063A190.pdf. 
Samanlioglu, Funda. 2013. "A Multi-Objective Mathematical Model for the Industrial Hazardous Waste Location-Routing Problem." European Journal of Operational Research 226 (2): 332-40. https://doi.org/10.1016/j.ejor.2012.11.019.

Scheuten, Frank-J. 2012. "Die Optimierung der Nachbetriebsphase." International Journal for Nuclear Power, Atomrecht Nachbetriebsphase, 57. Jg. (Heft 3). http://www.kernenergie.de/kernenergiewAssets/docs/fachzeitschrift-atw/2012/atw2012_03_scheuten_nachbetriebsphase.pdf.

Schneider, Mycle, Antony Froggatt, Phil Johnstone, Andy Stirling, Tadahiro Katsuta, M. V. Ramana, Christian von Hirschhausen, Ben Wealer, Agnès Stienne, and Julie Hazemann. 2018. "World Nuclear Industry Status Report 2018." Paris, London: Mycle Schneider Consulting.

Sheu, Jiuh-Biing. 2008. "Green Supply Chain Management, Reverse Logistics and Nuclear Power Generation." Transportation Research Part E: Logistics and Transportation Review 44 (1): 19-46. https://doi.org/10.1016/j.tre.2006.06.001.

Siempelkamp. 2015. "Bevorstehende Herausforderungen Beim Rückbau Kerntechnischer Anlagen." presented at the Kernenergetisches Symposium, Dresden, October 15.

Sorenson, Ken B, ed. 2012. Safe and Secure Transport and Storage of Radioactive Materials. Woodhead Publishing in Energy, no. 78. Woodhead Publishing.

Stahl, Thorsten, and Erik Strub. 2012. "Decommissioning of Nuclear Facilities." GRS-Gesellschaft für Anlagen-und Reaktorsicherheit (2012): Decommissioning of Nuclear Facilites. Hg. Von GRS mbH. Köln. Gesellschaft für Anlagen- und Reaktorsicherheit (GRS) mbH. http://www.grs.de/sites/default/files/pdf/GRS-S-52.pdf.

Surrey, John. 1992. "Ethics of Nuclear Decommissioning." Energy Policy, The first 50 years of nuclear power: legacy and lessons - Part 1, 20 (7): 632-40. https://doi.org/10.1016/0301-4215(92)90005M.

swissnuclear. 2011. "Kostenstudie 2011 (KS11) Schätzung der Kosten der NBP der SChweizer KKW." Olten, Schweiz. http://www.bfe.admin.ch/php/modules/publikationen/stream.php?extlang=de\&name=de_7981358 60.pdf.

Thierfeldt, S., and F. Schartmann. 2009. Stilllegung Und Rückbau Kerntechnischer Anlagen. Brenk Systemplanung. http://www.entsorgungsforschung.de/ptka-wte-e/WTE-E-EntsorgungsforschungBroschuere_Stilllegung-und-Rueckbau_BRENK.pdf.

Thomauske, Bruno. 2015. "Current Status of the Final Disposal of High-Level Waste in Germany." presented at the ICOND, Bonn, November 17.

Trück, Peter, and Berthold Oberle. 2013. "Rückbau von Kernkraftwerken: Der 500-Milliarden-Euro-Markt," BWk, $65 \quad$ (9). $\quad$ https://www.rochusmummert.com/downloads/news/91_sbb8514_rochus_mummert_bwk_kernkraftwerke.pdf.

UM. 2015. "Bericht über die Entsorgung von radioaktiven Abfällen und abgebrannten Brennelementen aus Baden-Württemberg." Ministry of Environement, Clima and Energy Baden-Württemberg. https://um.baden-wuerttemberg.de/fileadmin/redaktion/mum/intern/Dateien/Dokumente/3_Umwelt/Kernenergie/Entsorgung_und_Abbau/Entsorgungsberic ht.pdf.

VGB PowerTech e.V. 2012. "Entsorgung von Kernkraftwerken: Eine technisch gelöste Aufgabe." Essen. https://www.vgb.org/oppmultimedia/VGB_Brosch_Entsorgung_web-p-758.pdf.

Wasinger, Karl. 2015. "Change-Management - Vom Leistungsbetrieb Über Den Nachbetrieb Zum Rückbau." Atw - International Journal for Nuclear Power Vol. 60 (2): 90-92.

Wealer, Ben, Simon Bauer, and Christian von Hirschhausen. 2017. "Decommissioning: Survey of International Experiences with Focus on Germany, France, Japan and South Korea and the U.S." presented at the 2nd World Nuclear Decommissioning \& Waste Management Congress (Europe) 2017, London, September 11.

Wealer, Ben, Simon Bauer, Nicolas Landry, Hannah Seiß, and Christian von Hirschhausen. 2018a. "Nuclear Power Reactors Worldwide - Technology Developments, Diffusion Patterns, and Countryby-Country Analysis of Implementation (1951-2017)." DIW Berlin, Data Documentation 93. Berlin, Germany: DIW Berlin, TU Berlin. 
2018b. "Nuclear Power Reactors Worldwide - Technology Developments, Diffusion Patterns, and Country-by-Country Analysis of Implementation (1951-2017)." DIW Berlin, Data Documentation 93. Berlin, Germany: DIW Berlin, TU Berlin.

Wealer, Ben, Victoria Czempinski, Christian von Hirschhausen, and Sebastian Wegel. 2017. "Nuclear Energy Policy in the United States: Between Rocks and Hard Places." IAEE Energy Forum, no. Second Quarter 2017: 25-29.

Wealer, Ben, Clemens Gerbaulet, Christian von Hirschhausen, and Jan Paul Seidel. 2015a. "Stand und Perspektiven des Rückbaus von Kernkraftwerken in Deutschland (»Rückbau-Monitoring 2015«)." Data Documentation $\quad 81 . \quad$ DIW http://www.diw.de/de/diw_01.c.100407.de/publikationen_veranstaltungen/publikationen/data_doc umentation/data_documentation.html.

2015b. "Stand und Perspektiven des Rückbaus von Kernkraftwerken in Deutschland (»RückbauMonitoring 2015«)." DIW Berlin, Data Documentation 81. Berlin, Germany: DIW Berlin, TU Berlin.

Wealer, Ben, Seidel Jan Paul, Clemens Gerbaulet, and Christian von Hischhausen. 2015. "Stand und Perspektiven des Rückbaus von Kernkraftwerken in Deutschland." Data Documentation 81. DIW Berlin.

http://www.diw.de/de/diw_01.c.100407.de/publikationen_veranstaltungen/publikationen/data_doc umentation/data_documentation.html.

Westinghouse. Press release. 2015a. "Westinghouse-Led Consortium Awarded Segmentation of Reactor Pressure Vessel and Internals at Philippsburg Nuclear Power Plant Unit 1," 2015. http://www.westinghousenuclear.com/uknuclear/About/News/View/Westinghouse-led-

Consortium-Awarded-Segmentation-of-Reactor-Pressure-Vessel-and-Internals-at-PhilippsburgNuclear-Power-Plant-Unit-1.

Press release. 2015b. "Http://Www.Westinghousenuclear.Com/About/News/View/Westinghouseand-Hochtief-Team-to-Provide-End-of-Life-Services-for-German-Nuclear-Plants," March 26, 2015. http://www.westinghousenuclear.com/About/News/View/Westinghouse-and-Hochtief-Team-to-

Provide-End-of-life-Services-for-German-Nuclear-Plants.

Wetzel, Daniel. 2016. "AKWs: Deutschlands absurdes Konzept für den Atomausstieg." die Welt, March 10, 2016, sec. Wirtschaft. http://www.welt.de/wirtschaft/article153152032/So-absurd-umstaendlichverschrotten-wir-unsere-AKWs.html.

Wieland-Böse, Heike, and Martin Jonas. 2015a. "Gutachtliche Stellungnahme zur Bewertung der Rückstellungen im Kernenergiebereich." Düsseldorf: Warth \& Klein Grant Thornton AG. http://www.bmwi.de/BMWi/Redaktion/PDF/S-

T/stresstestkernenergie, property=pdf,bereich=bmwi2012,sprache=de,rwb=true.pdf.

2015b. "Gutachtliche Stellungnahme zur Bewertung der Rückstellungen im Kernenergiebereich." Düsseldorf: Warth \& Klein Grant Thornton AG. http://www.bmwi.de/BMWi/Redaktion/PDF/ST/stresstestkernenergie, property=pdf,bereich=bmwi2012,sprache=de,rwb=true.pdf.

Williams, Daniel G. 2007. "U.S. Nuclear Plant Decommissioning Funding Adequacy — by Individual Funds, Utilities, Reactors, and Industry-Wide - Assessed by Monte Carlo and Baseline Trend Methods: 1998, 2000, 2001, and 2004." Energy Economics 29 (5): 1050-1100. https://doi.org/10.1016/j.eneco.2006.03.004. 


\section{Appendix}

Table A1: Model sets, parameter, scalars and variables.

\begin{tabular}{|c|c|}
\hline $\begin{array}{l}\text { Symbol } \\
\text { Sets }\end{array}$ & Description \\
\hline $\begin{array}{l}y \\
n \\
r(n) \\
i \\
\operatorname{alias}(n, m) \\
\operatorname{alias}(i, j) \\
o \\
p \\
d(n) \\
s(n) \\
c(n) \\
k(n) \\
\text { Parameters }\end{array}$ & $\begin{array}{l}\text { Set of options } o \\
\text { Set of decommissioning phases } p \\
\text { Set of depots } d \text { as subset of nodes } \mathrm{n} \\
\text { Set of on-site storage facilities } s \text { as subset of nodes } \mathrm{n} \\
\text { Set of central storages facilities } c \text { as subset of nodes } \mathrm{n} \\
\text { Final storages facility Konrad } k \text { as subset of nodes } \mathrm{n}\end{array}$ \\
\hline 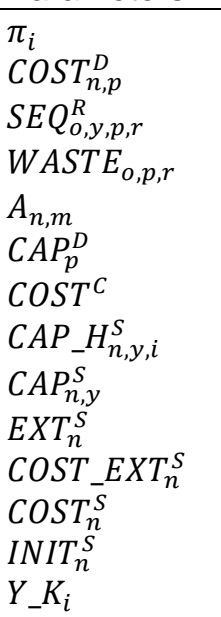 & $\begin{array}{l}\text { Probability of occurrence assigned to scenario } i \in[0,1] \\
\text { Annual dismantling costs for a reactor } r \text { in dismantling phase } p\left[E U R_{2016}\right] \\
\text { Active phase } p \text { in option } o \text { in year } y \text { for reactor } r \\
\text { Amount of waste from reactor } r \text { in phase } p \text { in option } o \text { is chosen }\left[\mathrm{m}^{3}\right] \\
\text { Adjacency matrix of arcs admissible for transportation of waste } \\
\text { Total dismantling capacity available for phase } p \\
\text { Average container cost }\left[E U R_{2016} / \mathrm{m}^{3}\right] \\
\text { Annual nuclear handling capacity at node } n \text { in year } y \text { in scenario } i\left[\mathrm{~m}^{3}\right] \\
\text { Storage capacity at node } n \text { without storage extension }\left[\mathrm{m}^{3}\right] \\
\text { Possible storage capacity extension at on-site storage } s\left[\mathrm{~m}^{3}\right] \\
\text { Costs for storage capacity extension at on-site storages } s\left[E U R_{2016}\right] \\
\text { Annual storage costs for storage at node } n\left[E U R_{2016}\right] \\
\text { Initial stock of waste at node } n\left[\mathrm{~m}^{3}\right] \\
\text { Opening year of Konrad depending on scenario }[y e a r]\end{array}$ \\
\hline Scalars & \\
\hline $\begin{array}{l}Y_{-} S \\
\delta \\
\operatorname{COST}^{T}\end{array}$ & $\begin{array}{l}\text { Start year of the Model }[y e a r] \\
\text { Discount factor } \\
\text { Fixed charge for transport between two nodes }[E U R]\end{array}$ \\
\hline Variables & \\
\hline $\begin{array}{l}\text { level }_{y, n, i}^{S} \\
\text { trans }_{n, m, y, i} \\
b_{\text {boption }}^{R} \\
\text { b_side }_{n, i}^{S} \\
\text { b_trans }_{y, n, m, i}\end{array}$ & $\begin{array}{l}\text { Storage level of waste at node } n \text { in year } y\left[\mathrm{~m}^{3}\right] \\
\text { Quantity of waste transported in year } y \text { in scenario } i \text { from node } n \text { to } m\left[\mathrm{~m}^{3}\right] \\
1 \text { if dismantling option } o \text { chosen for reactor } r \\
1 \text { if on-site storage is expended } \\
1 \text { if waste transport occurs between two nodes in year } y \text { in scenario } i\end{array}$ \\
\hline
\end{tabular}

Variables are denoted in bold while parameters are written in capital letters. 
Table A2: List of nuclear reactors in Germany by reactor type, ownership and shutdown date.

\begin{tabular}{|c|c|c|c|}
\hline Reactor & $\begin{array}{l}\text { Reactor } \\
\text { type }^{\mathrm{a}}\end{array}$ & Ownership & $\begin{array}{l}\text { Shut } \\
\text { Down } \\
\text { Date }\end{array}$ \\
\hline Biblis-A (KWB A) & PWR & RWE AG & 2011 \\
\hline Biblis-B (KWB B) & PWR & RWE AG & 2011 \\
\hline Brokdorf (KBR) & PWR & PreussenElektra (80\%), Vattenfall (20\%) & 2021 \\
\hline Brunsbüttel (KKB) & BWR & Vattenfall (66.6\%), PreussenElektra (33.3\%) & 2011 \\
\hline Emsland (KKE) & PWR & RWE (87.5\%), PreussenElektra (12.5\%) & 2022 \\
\hline Grafenrheinfeld (KKG) & PWR & PreussenElektra & 2015 \\
\hline Grohnde (KWG) & PWR & PreussenElektra (83.3\%), SW Bielefeld (16.7\%) & 2021 \\
\hline Gundremmingen-A (KRB A) & BWR & RWE (75\%), PreussenElektra (25\%) & 1977 \\
\hline Gundremmingen-B (KRB B) & BWR & RWE (75\%), PreussenElektra (25\%) & 2017 \\
\hline Gundremmingen-C (KRB C) & BWR & RWE (75\%), PreussenElektra (25\%) & 2021 \\
\hline Isar-1 (KKI 1) & BWR & PreussenElektra & 2011 \\
\hline Isar-2 (KKI 2) & PWR & PreussenElektra (75\%), SW München (25\%) & 2022 \\
\hline Krümmel (KKK) & BWR & Vattenfall (50\%), PreussenElektra (50\%) & 2011 \\
\hline Lingen (KWL) & BWR & RWE AG & 1977 \\
\hline Mülheim-Kärlich (KMK) & PWR & RWE AG & 1988 \\
\hline Neckarwestheim-1 (GKN 1) & PWR & EnBW & 2011 \\
\hline Neckarwestheim-2 (GKN 2) & PWR & EnBW & 2022 \\
\hline Obrigheim (KWO) & PWR & EnBW & 2005 \\
\hline Philippsburg-1 (KKP 1) & BWR & EnBW & 2011 \\
\hline Philippsburg-2 (KKP 2) & PWR & EnBW & 2019 \\
\hline Stade (KKS) & PWR & PreussenElektra (66.7\%), Vattenfall (33.3\%) & 2003 \\
\hline Unterweser (KKU) & PWR & PreussenElektra & 2011 \\
\hline Würgassen (KWW) & PWR & PreussenElektra & 1994 \\
\hline
\end{tabular}

a PWR: Pressurized Water Reactors, BWR: Boiling Water Reactors

Source: Own depiction based on IAEA (2018) and Wealer et al. (2015). 


\section{Supplementary Material}

\section{Detailed Model Results}

\subsection{Case 1: Base Case:}

One Scenario Konrad Opening 2022; No Capacity Restriction for Dismantling Activities

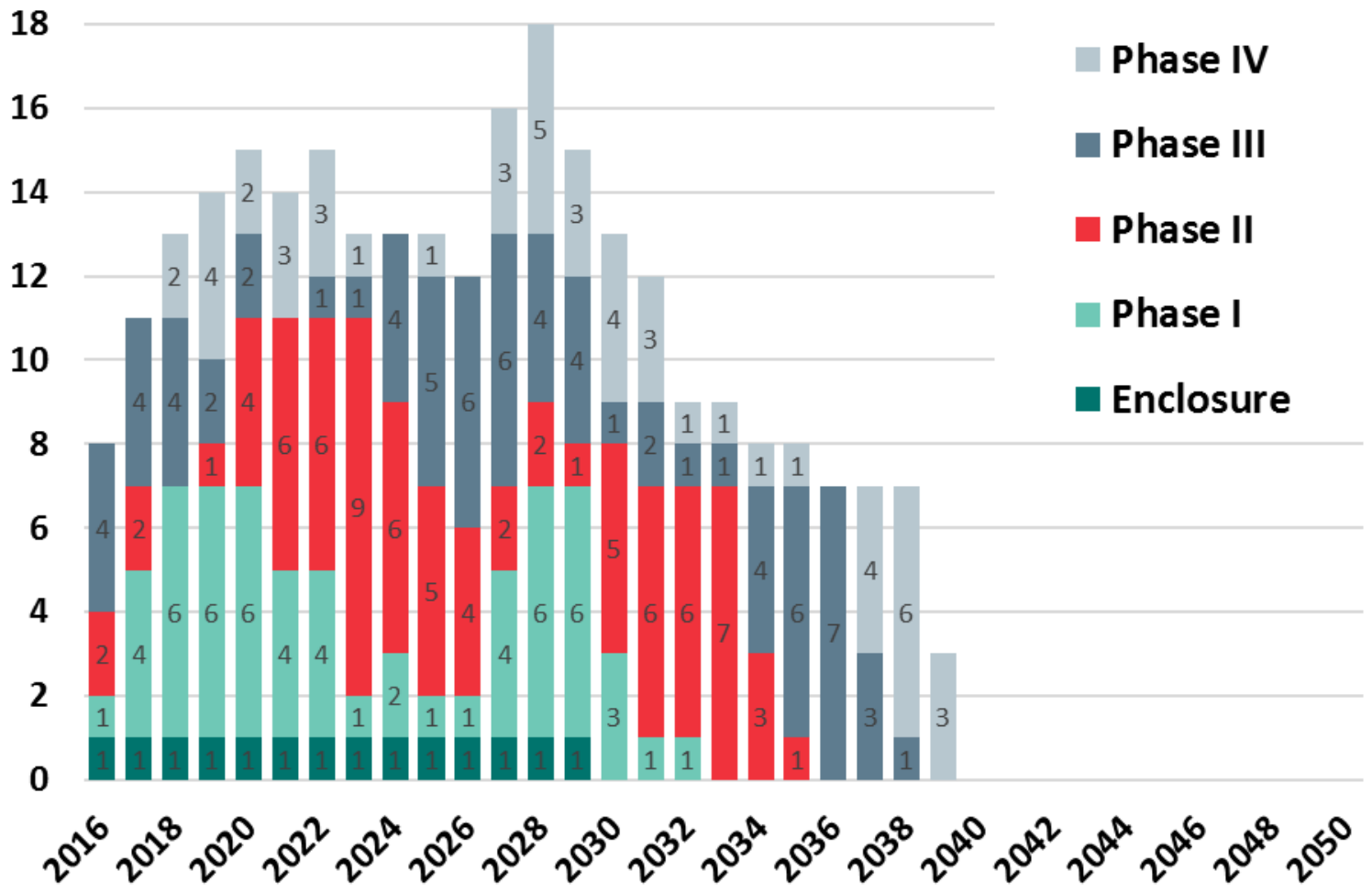

Figure 8: Reactors by physical dismantling phase in Case 1 - Base Case

In Case 1, no delays in terms of waiting periods are needed (Figure 8). In 2029 a peak of 17 reactors, being in a physical dismantling phase at the same time is reached. In 2023, 9 reactors are in Phase II and a maximum of 7 reactors are in Phase III in 2036. These two phases include the technically most challenging work packages with a high need for specialized engineering. 


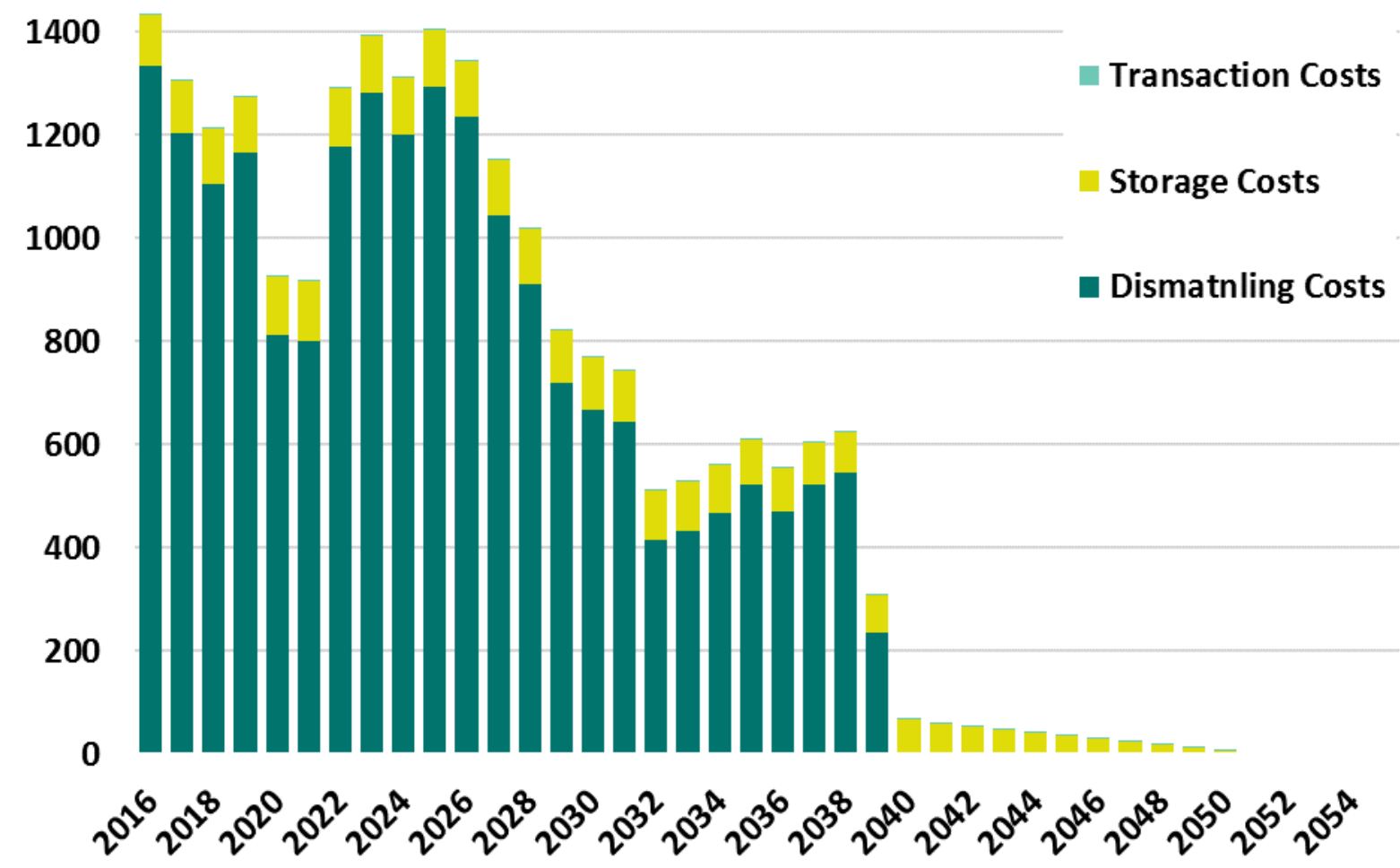

Figure 9: Yearly costs in million EUR in Case 1 - Base Case.

The direct dismantling of all reactors leads to the accumulation of costs especially from 2022 until 2026.

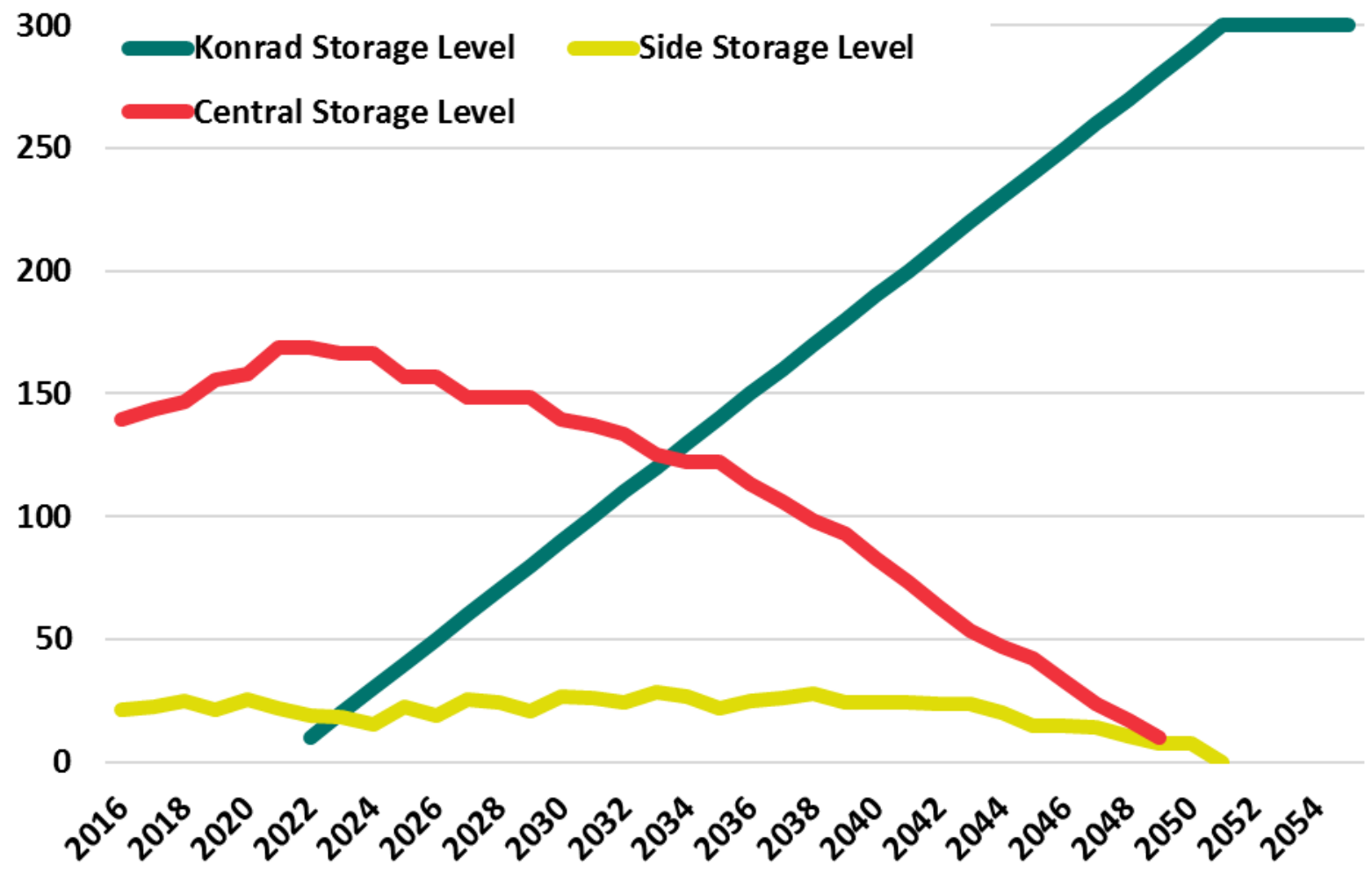

Figure 10: Storage level in thousand $\mathrm{m}^{3}$ in Case 1- Base Case.

The development of the storage levels indicates that additional on-site storage facilities are not needed in Case 1 . The waste mainly accumulates in the central storage facilities due to lower storage costs or is 
directly transported to Konrad as soon as it is available in 2022. All waste is stored in Konrad by 2052 (Figure 10).

\subsection{Case 2: Late Konrad}

Two Scenarios (s22 and s32) with Konrad Opening in 2022 and 2032; NO Capacity Restriction for Dismantling Activities.

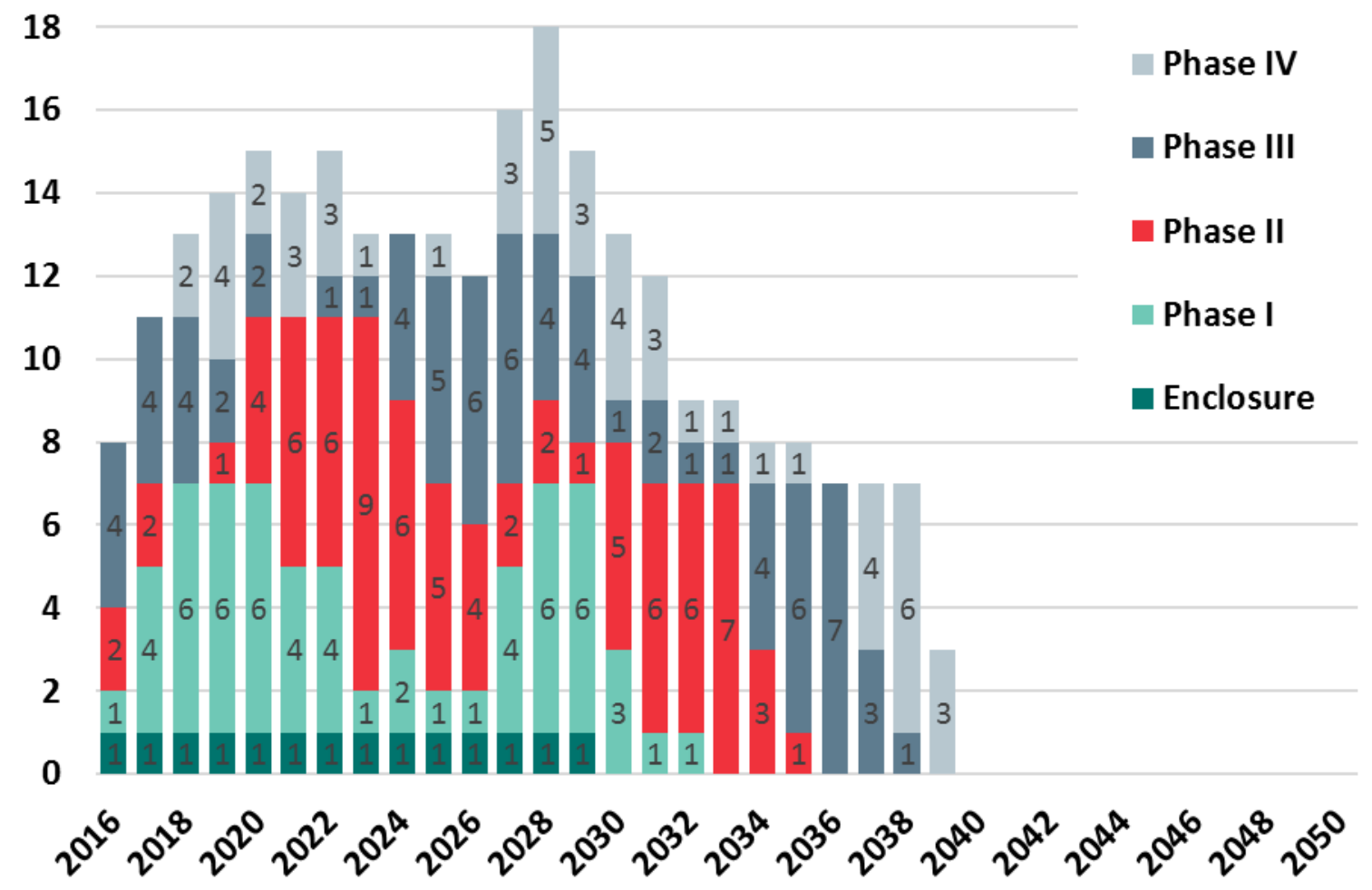

Figure 11: Reactors by Phase in Case 2 - Late Konrad.

The distribution of yearly costs does not significantly vary in comparison to Case 1. Especially the increased use of on-site storage facilities can be observed in scenario s32, where also the central storage Facilities reach their capacity (Figure 12). An additional 13 on site storage facilities are built if Konrad is not to be open before 2032 . 


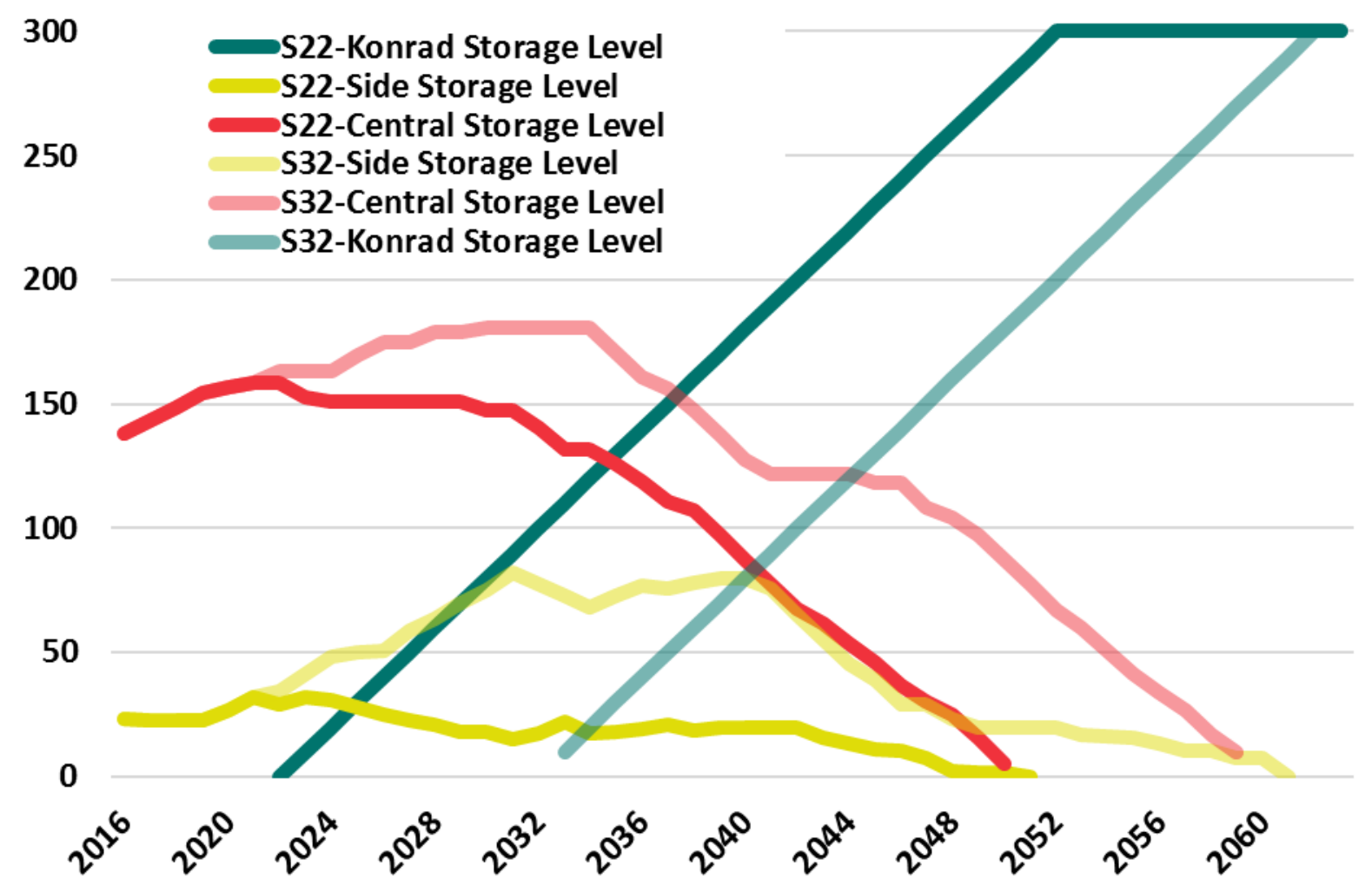

Figure 12: Storage level in thousand $\mathrm{m}^{3}$ depending on scenarios in Case 2- Late Konrad.

\subsection{Case 3: Capacity Restriction.}

One scenario (s22) with Konrad opening 2022 and capacity restrictions for dismantling activities.

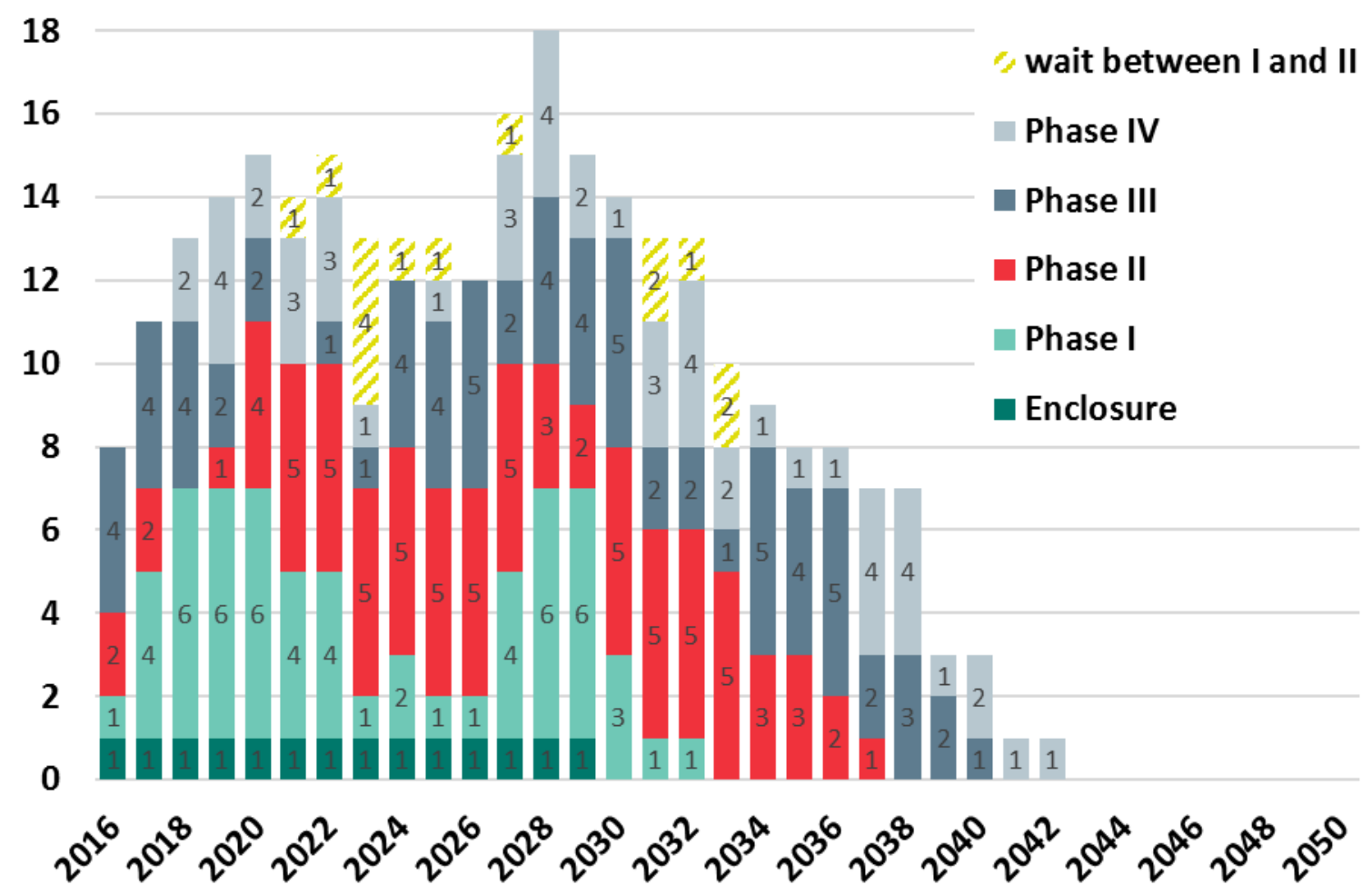

Figure 13: Reactors by phase in Case 3 - Capacity Restriction. 


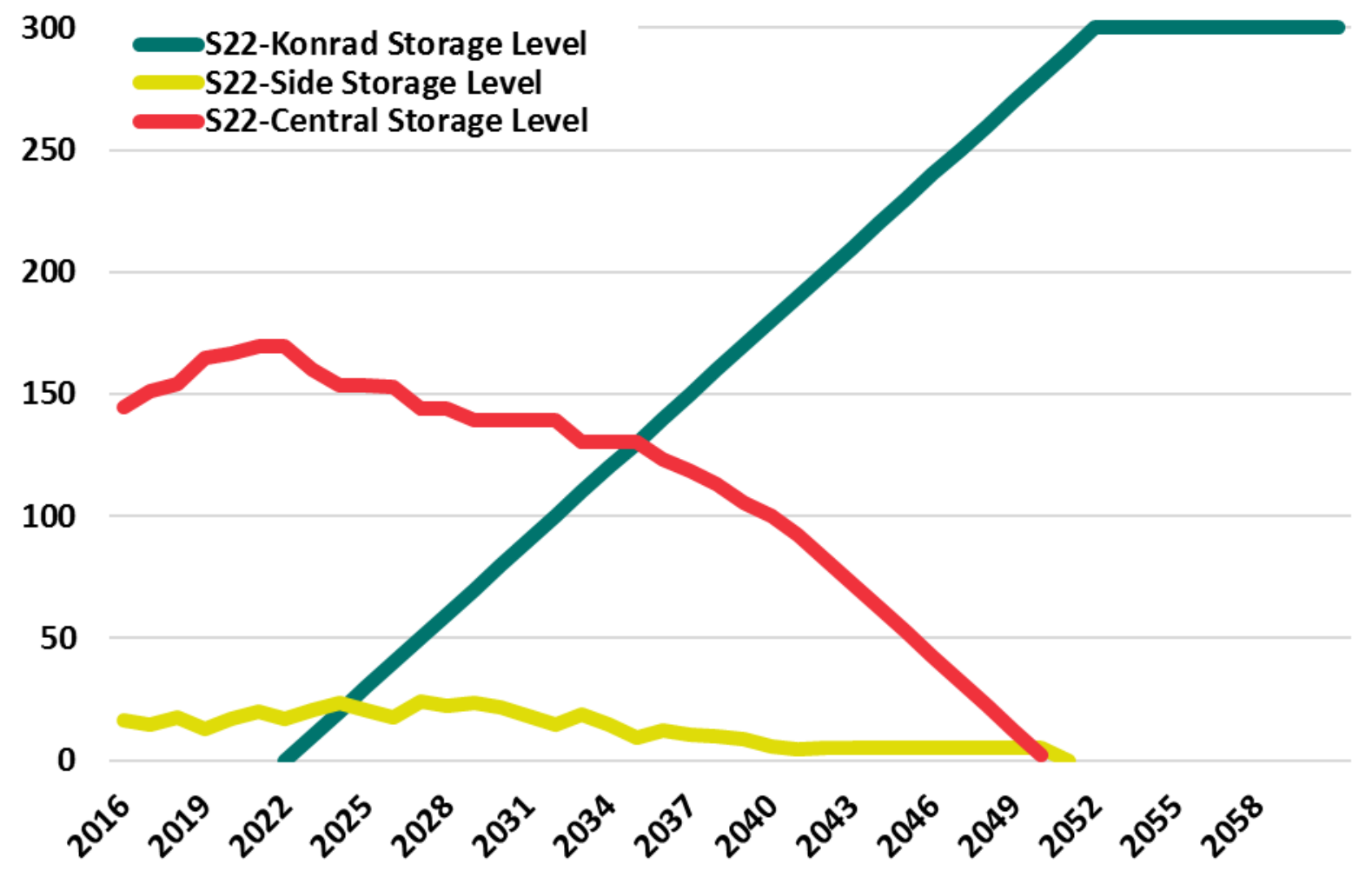

Figure 14: Storage level in thousand $\mathrm{m}^{3}$ in Case 3 - Capacity Restriction.

In Case 3, the closure of Konrad is not impacted by the slight delay of dismantling compared to the Base Case. Therefore, not additional operating cost for a prolonged operation time at Konrad must be expected. 


\subsection{Case 4 - Late Konrad and Capacity Restriction}

Two scenarios (s22 and s32) with Konrad opening 2022 or 2032 and capacity restrictions for dismantling activities.

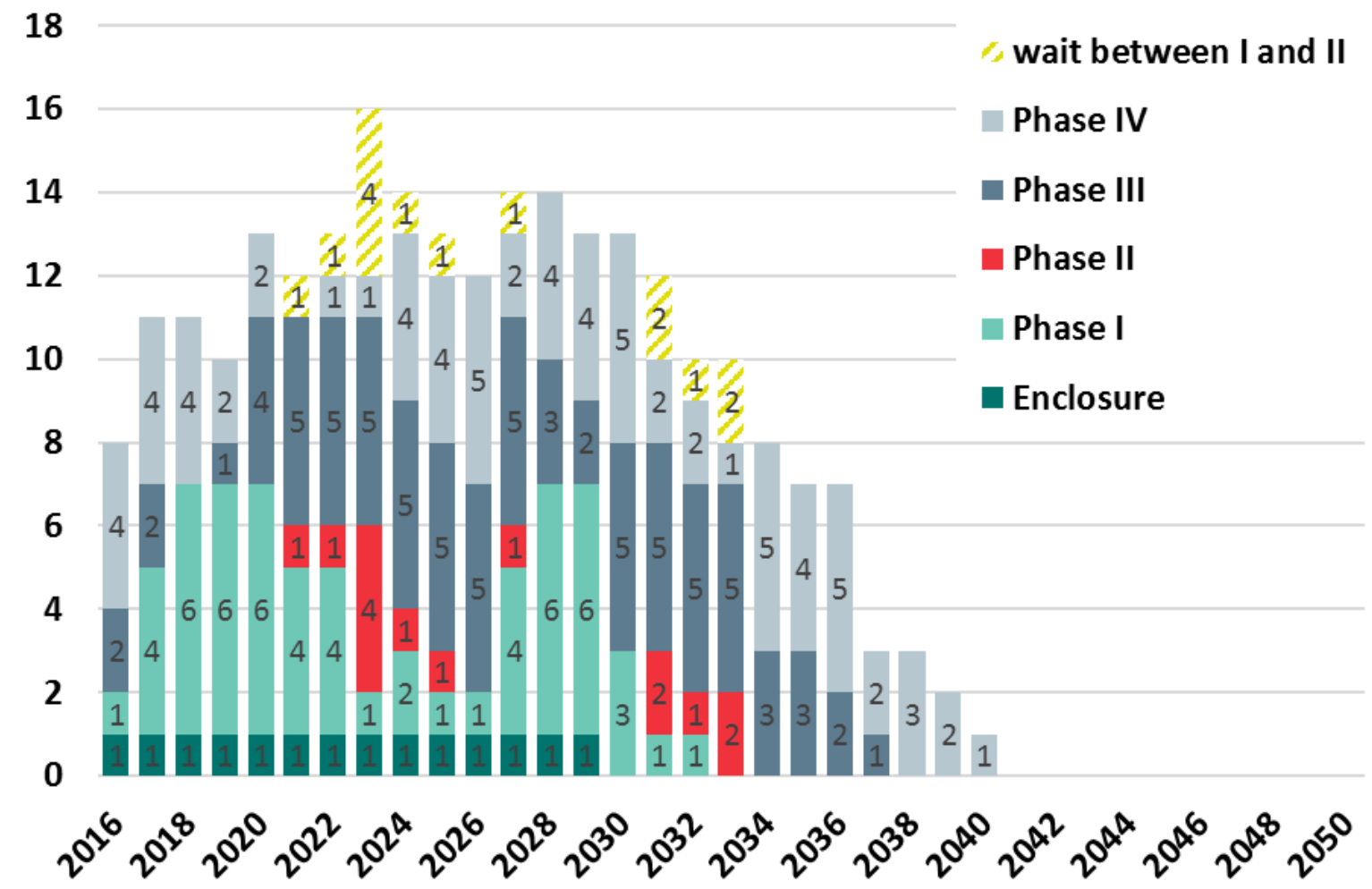

Figure 15: Reactors by phase in Case 4 - Late Konrad and Capacity Restriction. 


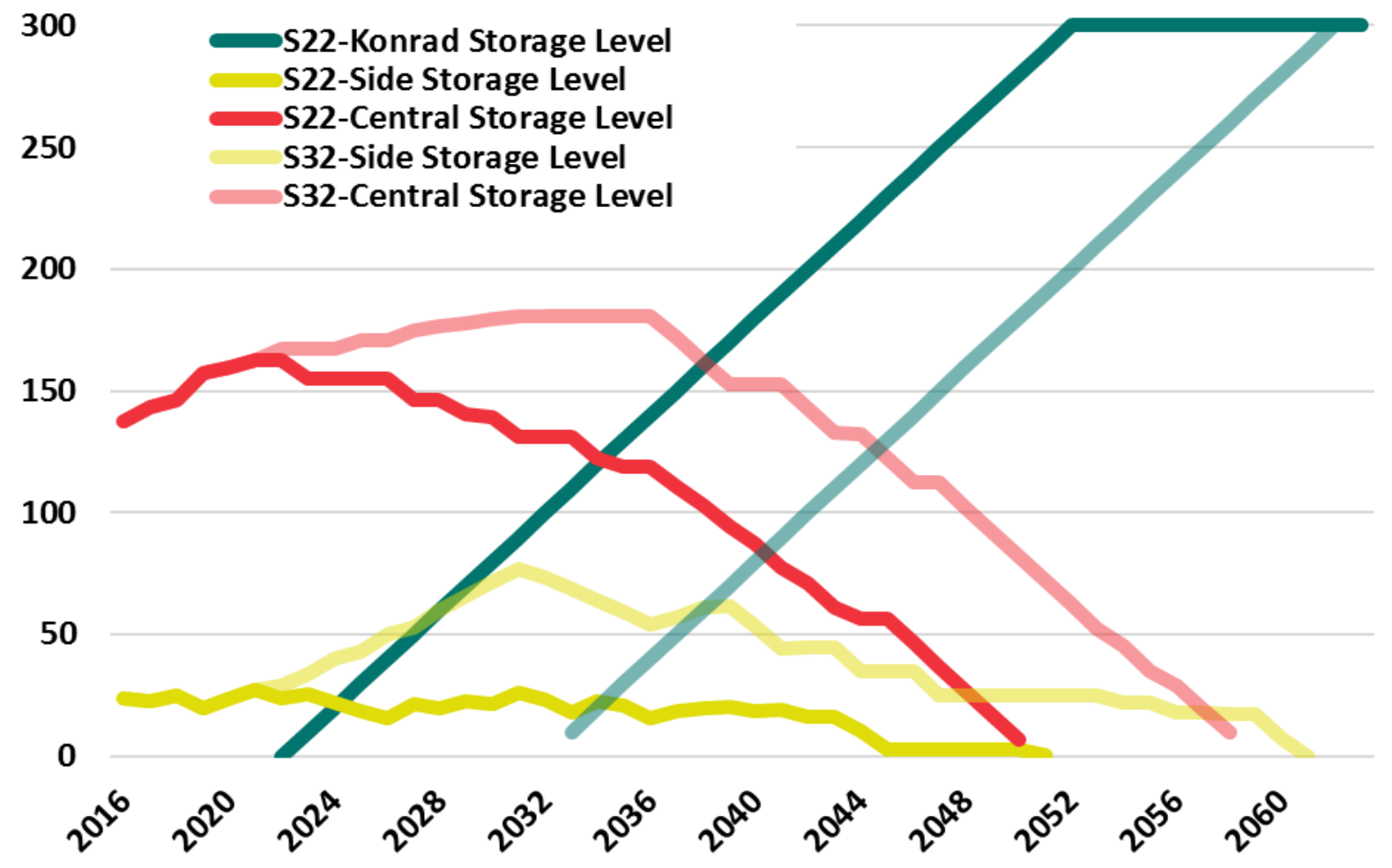

Figure 16: Storage level in thousand $\mathrm{m} 3$ in Case 4 - Late Konrad and Capacity Restriction.

\section{Data and Assumptions}

To assess the decommissioning process in Germany (focusing on LLW and ILW), we have compiled an extensive dataset. Parameters combine information from various sources while own assumptions where also necessary. This section focuses on the crucial assumptions and provides a detailed discussion of parameters concerning waste volumes, storage capacities and most importantly cost figures.

\subsection{Storage Capacities and Waste Volumes}

Rough estimates on the amount and timing of occurrence of LLW and ILW are available from BMUB (2015) (cf. Table S1 ). However, the model required a detailed assignment of waste for each reactor and storage facility. The facility specific register of stored nuclear waste by BMUB (2014) together with the database "Atommüllreport" maintained by the working group "Arbeitsgemeinschaft Schacht KONRAD e.V." allowed a facility specific assignment of waste (Albrecht et al. 2016). Values reported in BMUB (2014) are often provided in terms of unconditioned waste or packaged in containers other than those meeting Konrad requirements. To achieve consistency, we assumed volumes of waste conditioned and packaged for Konrad measured in $\mathrm{m}^{3}$. For conversion, we multiply unconditioned or badly packaged volumes already stored in interim facilities with a factor of $1.1 .{ }^{20}$

${ }^{20}$ The factor ensure that total volumes estimated by BMUB (2015) are met when summing up individual amounts. 
Table S1: Comparison of BMUB estimates of LLW and ILW to be stored in Konrad with own calculation (in $\mathrm{m}^{3}$ ).

\begin{tabular}{|c|c|c|c|c|c|}
\hline & $\begin{array}{l}\text { VBG Power } \\
\text { Tech e.V. } \\
(2012)\end{array}$ & $\begin{array}{l}\text { Own } \\
\text { calculation } \\
(1)\end{array}$ & $\begin{array}{l}\text { To Model } \\
\text { (2) }\end{array}$ & & $\begin{array}{l}\text { BMUB } \\
(2015)\end{array}$ \\
\hline $\begin{array}{l}\text { Waste from } \\
\text { operation after } 2016\end{array}$ & & 1662 & 1662 & $\begin{array}{l}\text { Total waste from } \\
\text { NPPs until } 2050\end{array}$ & 190000 \\
\hline $\begin{array}{l}\text { Waste from } \\
\text { dismantling NPPs } \\
\text { after } 2016\end{array}$ & 115000 & 134250 & 134250 & $\begin{array}{l}\text { Total waste from } \\
\text { Research until } \\
2080\end{array}$ & 65000 \\
\hline $\begin{array}{l}\text { Waste in interim } \\
\text { storage facilities } \\
2015\end{array}$ & & 146117 & 160728 & $\begin{array}{l}\text { Nuclear industry, } \\
\text { storage, } \\
\text { reprocessing until } \\
2010\end{array}$ & 48000 \\
\hline \multicolumn{2}{|l|}{ Total LLW and ILW } & 282029 & 296640 & Total LLW and ILW & 303000 \\
\hline
\end{tabular}

Source: own compilation based on BMUB (2014, 2015); Albrecht et al. (2016); VGB Power Tech e.V. (2012).

BfS (2015) reports an amount of on average $5000 \mathrm{~m}^{3}$ of LLW and ILW waste resulting from the dismantling process per reactor that must be stored in a final storage facility. Köhlmann $(2008,44)$ cites more refined estimates on the reactor type level and by dismantling option: $5200 \mathrm{~m}^{3}$ for Pressurized Water Reactors (PWR) and $6800 \mathrm{~m}^{3}$ for Boiling Water Reactors (BWR) for direct dismantling and reduced volumes of 4100 $\mathrm{m}^{3}$ for PWR and $5400 \mathrm{~m}^{3}$ for BWR with the enclosure option. Although reactor type and size are good first indicators of resulting waste volumes, the full extent of contamination is specific to each individual reactor and can only be examined during the dismantling process itself. Data from current decommissioning operations show significant variation and exceeds BfS estimate of $5000 \mathrm{~m}^{3}$ (cf. Table S2). Finally, an amount of $6500 \mathrm{~m}^{3}$ for all reactors is found best to consider the risks of having higher contaminations than expected and being fully consistent with overall estimates from BMUB (2015).

Table S2: Available plant specific estimates for LLW and ILW volumes in Germany.

\begin{tabular}{llll}
\hline \hline Units(s) & Reactor type & Reactor size & Expected LLW and ILW $\left[\mathrm{m}^{3}\right]$ \\
\hline Obrigheim (KWO) & PWR & $357 \mathrm{MW}$ & 3700 \\
Neckarwestheim 1 (GKN-1) & 2x PWR & $1 \times 785 \mathrm{MW}$ & 12900 \\
Neckarwestheim 2 (GKN-1) & & $1 \times 1310 \mathrm{MW}$ & \\
Phillipsburg 1 KKP-1 & $1 \times$ BWR & $890 \mathrm{MW})$ & 15300 \\
Phillipsburg 2 KKP-2 & $1 \times$ PWR & $1402 \mathrm{MW})$ & \\
\hline \hline
\end{tabular}

Source: Own depiction based on UM $(2015,17-19)$.

\subsection{Waste Volumes and the Regulatory Framework - Upcoming Revision of the Radiation Protection Act (StrlschV)}

The clearance of waste for conventional disposal is an essential part of the decommissioning process in Germany. After the release from the jurisdiction of the atomic law (Atomgesetz, AtG), the waste can be disposed of in accordance with the regulations of the conventional waste and recycling economy (Thierfeldt and Schartmann 2009, 75). A report of Entsorgungskommission ESK states that $92 \%$ of the total mass stemming from the area within the containment structure is released without any restriction (ESK 2014, 3). These proportions underline the importance of this measure for an efficient decommissioning process. In addition to the clearance without restrictions there is also the possibility of clearance restricted to a specified 
purpose or disposal site. A restriction might be the obligation to dispose the waste in a waste incineration plant or to place it on a waste disposal site (German Office of Radiation Protection 2016, §29). If clearance is not possible, materials must be placed in a final storage facility, which is associated which high costs. Furthermore, capacities of the final storage facility Konrad are fully allocated to forecasted waste volumes as described in section 2.5. This fact might prove itself to be critical as the exact volume of waste occurring during the dismantling highly depends on the extent of the contamination, which can only be assessed during the dismantling process ${ }^{21}$.

With the obligatory implementation of the directive 2013/59/Euratom in national law until February 2018, a revised and tightened set of exemption and clearance criteria will come into force. Application of these new values can lead to increasing waste volumes and additional costs. The new law is expected to mostly impact LLW, which can be released from surveillance under German Nuclear Law without any restriction. Even though no impact on the volume of waste in need of storing is expected at the moment it may lead to increasing costs. The effect of changing clearance and exemption level on waste volumes is generally outlined by Agneb (2015).

\subsection{Decommissioning options and associated costs}

According to the Nuclear Agency (NEA) of the $\operatorname{OCED}(2016,58)$ there is currently no universally accepted standard for developing decommissioning cost estimates, which creates considerable barriers for comparison between different estimates. State-of-the-art decommissioning cost estimates perform a sitespecific bottom-up analysis which either relies on a reference system (Germany, heavy water moderated gas cooled reactor of $100 \mathrm{MWe}$ ) or on a database classifying individual rooms and components within them (Spain and France) (LaGuardia and Murphy 2012, 12). International Structure for Decommissioning Costing (ISDC) of Nuclear Installations are an attempt by NEA to introduce an itemization of decommissioning costs within a common reporting structure (cf. NEA 2012). NEA (2016) provides a comparison of decommissioning costs based on ISDC from case studies of European decommissioning projects and a conversion of US case studies into the ISDC system originating from a comprehensive PNNL (2012) study. Due to a lack of site-specific information that are publicly available other than reactor type and nominal capacity, we rely on aggregate parametric estimates.

NEA reports decommissioning cost of 240 to 1,200 Mio. USD 2013 per reactor or 0.2 to 1.2 Mio USD 2013 per MWe (own calculation based on NEA 2016 tables 3.5, and 3.13), FÖS (2012) and Klasen and Burkhard (2015b) assume dismantling cost of 1 bn EUR per reactor in Germany. Based on data provided by the utilities owning nuclear power plants in Germany, Wieland-Böse and Jonas (2015a, table 14) calculate average cost of 857 Mio. EUR 2014 per reactor or 0.83 Mio EUR 2014 per MWe. They note, that figures for Germany are significantly higher compared to other countries, which can be explain by the less complex processes to release material from the surveillance under the Nuclear Law (e.g. France) and decommissioning methods that are not admitted in Germany (e.g. building implosion in the U.S.). We find the value put forward by Wieland-Böse and Jonas slightly flawed as it consideres only future dismantling costs but does not take the current state of dismantling of each reactor into account. Hence, to be consistent

\footnotetext{
${ }^{21}$ NPP Stade is a good example as contamination of the concrete base became visible only at a very late stage of the dismantling process (cf. Lower Saxony, Ministry for Environment, Energy, and Climate Protection 2014).
} 
in the Base Case with the overall dismantling cost used by the KFK of $17.32 \mathrm{bn}$ EUR $^{2016}$ and the literature we assume costs of 1.08 bn EUR per reactor.

In 2016 multiple reactors are in different phases of the dismantling process. Wealer et al. (2015) provide an extensive overview of the state of the decommissioning process for each reactor. These progresses are fully taken into account on a reactor level. Consequently, the starting year for presented scenarios is 2016 .

The costs are distributed on the different dismantling phases I-IV based on the technical tasks carried out in each phase described by Leidinger $(2015$, fol. 7$) .{ }^{22}$ The POP is the most expensive period with yearly costs of 73 Mio. EUR (swissnuclear 2011).

Even though the dismantling option enclosure is not available anymore in Germany, a corresponding cost estimate is available in the model database. As the main focus of the model is to evaluate the influence of uncertainties and capacity restriction, we rather focus on the ratio of costs among different alternatives than on the absolute values. Therefore, the costs for the enclosure option have been calculated by using the average ratio between realized costs for the options enclosure and direct projects concerning WWER 440 reactors evaluated in IAEA $(2002,81-83) .^{23}$ The costs for enclosure of a PWR are thus estimated to be 1.3 times more expensive than direct dismantling. ${ }^{24}$

One of the main issues governing the costs of decommissioning is the duration of the process. Again, estimates are very site-specific and vary significantly between different countries (ranging between 5 years in Finland to 15 years in Switzerland, after the completion of the POP phase) (NEA 2016, table 3.9). Due to the similarities in the regulatory framework and the nuclear reactor technology (i.e. Westinghouse and KWU PWRs and GE BWRs (Wealer et al. 2018b, 144-45)) we orientate towards figures from Switzerland.

\subsection{Transportation of ILW and LLW}

As transport of LLW and ILW is relatively cheap in comparison to dismantling cost, no transportation costs per $\mathrm{m}^{3}$ are considered, but costs for each executed transport. The transports of LLW and ILW waste from public facilities to Konrad have been assessed by Graffunder (2015, fol. 23) using a simulation model considering inter alia means of transport, capacity restrictions and stacking logic of transport containers. By using the number of transports resulting from the simulation model and cost estimate for transport activities from Knack (2012, fols. 26-27), average costs of 150.000 EUR per transport are calculated.

\footnotetext{
${ }^{22}$ This assumption bears in mind that a more detailed cost distribution during the phases cannot be justified due to a lack of sufficient and detailed sources and has a limited impact on our results due to the model structure. The distribution of costs heavily depends on the realization of milestones during the dismantling process (Klasen and Burkhard 2015b, fol. 9). It has to be mentioned that some sources suggest a steep decrease of yearly costs during the ongoing dismantling process (Leidinger 2015, fol. 16). From a modelling perspective, the detailed distribution has no impact on the optimal decisions, as the net present value in the first period of the actual dismantling process is the determining parameter. Nevertheless, the distribution has an impact on the yearly cost distribution displayed within the results.

${ }^{23}$ IAEA (2002, 81-83) refers to the option direct as immediate dismantling (ID) and to the option enclosure as safe enclosure (SE).

${ }^{24}$ Even though technical properties of WWER -440 reactors are significantly different, we assume the fundamental costs and benefits of changing from direct dismantling to the enclosure option to be the same for any reactor. Knack (2012, fol. 12) indicate why cost estimation relative to the direct option is difficult, as the direct impact of these points on the costs are difficult to assess and verify. Cost reducing: activity is reduced, which reduces costs for security measurements during dismantling; a greater part of the material can be reused; cost increasing: loss of knowledge and experience; control must be established for 30 years; safety relevant parts must be checked for 30 years additional lifetime; infrastructure like cranes and ventilation has to be assessed for 30 years.
} 


\subsection{Storage facilities}

The storage facilities consist of the decentralized storage facilities at the reactor sites and the centralized storage facilities for LLW and ILW: Gorleben, Ahaus, and central storage Nord (Zwischenlager Nord/Lubmin). The actual available storage space in on-site storage facilities available in the model is reduced by the factor $\mathbf{0 . 7}$, as it is assumed that these storage facilities are used for unconditioned waste with higher volumes during the dismantling phases. The total storage space is consequently not fully available. Storage costs of 386 EUR per $\mathrm{m}^{3}$ in central storage facilities have been calculated based on the overall value of storage services provided by GNS divided by the corresponding inventory (GNS 2015). Costs are assumed to be slightly cheaper in central storages compared to on-site storage facilities due to their larger size. The model can endogenously invest in additional on-site storage facilities, when needed. For the final storage facility Konrad an maximal annual store capacity of $10,000 \mathrm{~m}^{3}$ is considered as described in BfS and Grafunder (2016b; 2015).

\section{References}

Agneb (Swiss). 2015. "Auswirkungen einer verlängerten Abklinglagerung auf die radioaktiven Abfälle." Schweizer Arbeitsgruppe des Bundes für die nukleare Entsorgung, Untergruppe «Abklinglager». https://www.bag.admin.ch/dam/bag/de/dokumente/str/fanm/radioaktive-materialenabfaelle/agneb-auswirkungen-verlaengerten-abklinglagerung-radioaktiv.pdf.download.pdf/agnebauswirkungen-verlaengerten-abklinglagerung-radioaktiv.pdf.

Albrecht, Christina, Claudia Baitinger, Thorben Klages, Jutta Beckmann, Peter Dickel, Dieter Kaufmann, and Lothar Krause. 2016. "Atommüllreport Daten." Atommüllreport. 2016. http://www.atommuellreport.de/daten.html.

BfS. 2016b. "Geplante Einlagerung." Www.Endlager-Konrad.De. 2016b. http://www.endlagerkonrad.de/Konrad/DE/themen/einlagerung/einlagerung/einlagerung_node.html.

2015. "Reststoff- Und Abfallmanagement Bei Der Stillegung." September 9, 2015. http://www.bfs.de/DE/themen/kt/stilllegung/abfallmanagement/abfallmanagement_node.html.

BMUB. 2014. "Verzeichnis Radioaktiver Abfälle: Bestand Zum 31. Dezember 2013 Und Prognose." K-MAT 13. http://www.bundestag.de/blob/337852/7c57c8dc16bfc64f8ae86006964be6b2/kmat _13data.pdf Retrieved.

2015. "Report on the Cost and Financing of Disposal of Spent Fuel and Radioactive Waste." http://www.bmub.bund.de/fileadmin/Daten_BMU/Download_PDF/Nukleare_Sicherheit/abfallentso rgung_kosten_finanzierung_bf.pdf.

ESK. 2014. "Vergleich Der Massenströme Bei Der Stillegung von Kernkraftwerken in Deutschland Und Frankreich." Entsorgunskommission. http://www.entsorgungskommission.de/sites/default/files/reports/vergleichmassenstroeme_homep age.pdf.

FÖS. 2012. "Rückstellungen für Stillegung/Rückbau und Entsorgung im Atombereich: Thesen und Empfehlungen zu Reformoptionen." http://www.foes.de/pdf/2012-FOES-RueckstellungenAtom.pdf.

German Office of Radiation Protection. 2016. Verordnung Über Den Schutz Vor Schäden Durch Ionisierende Strahlen (Strahlenschutzverordnung - StrlSchV). RS -Handbuch. Vol. 1A-8. https://www.bfs.de/SharedDocs/Downloads/BfS/DE/rsh/1a-atomrecht/1A-8-

StrlSchV.pdf?_blob=publicationFile\&v=8.

GNS. 2015. "Jahresabschluss zum Geschäftsjahr vom 01.01.2014 bis zum 31.12.2014." Essen: Gesellschaft für Nuklear-Service mbH. https://www.bundesanzeiger.de/ebanzwww/wexsservlet.

Graffunder, Iris. 2015. "Waste Management for the Repository Konrad." presented at the ICON. 
IAEA. 2002. Decommissioning Costs of WWER-440 Nuclear Power Plants: Interim Report: Data Collection and Preliminary Evaluations. Vienna: International Atomic Energy Agency. http://wwwpub.iaea.org/MTCD/publications/PDF/te_1322_web.pdf.

Klasen, Jörg, and Seizer Burkhard. 2015. "Managing Complexity of Nuclear Decommissioning \& Dismantling Projects - An Advanced Project- Management Approach." presented at the ICOND, Bonn, November 18.

Knack, M. 2012. "Decommissioning - Three Main Strategies: Immediate Dismantling, Safe Enclosure (Deferred Dismantling), Entombment." presented at the IAEA RER/9/120 Workshop on planning and licensing of decommissioning projects, November 26. https://www.iaea.org/OurWork/ST/NE/NEFW/WTS-

Networks/IDN/idnfiles/WkpPlanLicencingDecomProjetc_Germany2012/WkpPlanLicencingDecom Projetc_Germany2012-Decommissioning_Strategies-Knaack.pdf.

Köhlmann, Sarah. 2008. Die Abbildung von nuklearen Entsorgungsverpflichtungen in IFRS-Abschlüssen: eine Analyse der Bilanzierung, Offenlegung und Prüfung. 1. Aufl. Gabler Edition Wissenschaft. Wiesbaden: Gabler.

LaGuardia, T. S., and K. C. Murphy. 2012. "4 - Financing and Economics of Nuclear Facility Decommissioning." In Nuclear Decommissioning, edited by Michele Laraia, 49-86. Woodhead Publishing Series in Energy. Woodhead Publishing. https://doi.org/10.1533/9780857095336.1.49.

Leidinger, Bernhard. 2015. "Cost Management during Decommissioning: What Are the Cost-Drivers." presented at the ICOND, Bonn, November 17.

Lower Saxony, Ministry for Environment, Energy, and Climate Protection. 2014. "Ereignisinformation Zum Kernkraftwerk Stade (KKS) | Nds. Ministerium Für Umwelt, Energie Und Klimaschutz." January 28, 2014. http://www.umwelt.niedersachsen.de/kernkraftwerk_stade/ereignisinformation-zumkernkraftwerk-stade-kks-129862.html.

NEA. 2012. "International Structure for Decommissioning Costing (ISDC) of Nuclear Installations." Paris, France: Organisation for Economic Co-operation and Development (OECD). www.oecdnea.org/rwm/reports/2012/ISDC-nuclear-installations.pdf.

2016. "Costs of Decommissioning Nuclear Power Plants." Nuclear Development. Paris, France: Organisation for Economic Co-operation and Development (OECD).

PNNL. 2012. "Assessment of the Adequacy of the 10 CFR 50.75(c) Minimum Decommissioning Fund Formula." NRC Job Code J-4275. Washington, D.C., USA: Office of Nuclear Reactor Regulation U.S. Nuclear Regulatory Commission. https://www.nrc.gov/docs/ML1306/ML13063A190.pdf.

Seidel, Jan Paul, Ben Wealer, Clemens Gerbaulet, and Christian von Hischhausen. 2015. "Stand und Perspektiven des Rückbaus von Kernkraftwerken in Deutschland." Data Documentation 81. DIW Berlin.

http://www.diw.de/de/diw_01.c.100407.de/publikationen_veranstaltungen/publikationen/data_doc umentation/data_documentation.html.

swissnuclear. 2011. "Kostenstudie 2011 (KS11) Schätzung der Kosten der NBP der SChweizer KKW." Olten, Schweiz. http://www.bfe.admin.ch/php/modules/publikationen/stream.php?extlang=de\&name=de_7981358 60.pdf.

Thierfeldt, S., and F. Schartmann. 2009. Stilllegung Und Rückbau Kerntechnischer Anlagen. Brenk Systemplanung. http://www.entsorgungsforschung.de/ptka-wte-e/WTE-E-EntsorgungsforschungBroschuere_Stilllegung-und-Rueckbau_BRENK.pdf.

UM. 2015. "Bericht über die Entsorgung von radioaktiven Abfällen und abgebrannten Brennelementen aus Baden-Württemberg." Ministry of Environement, Clima and Energy Baden-Württemberg. https://um.baden-wuerttemberg.de/fileadmin/redaktion/m-

um/intern/Dateien/Dokumente/3_Umwelt/Kernenergie/Entsorgung_und_Abbau/Entsorgungsberic ht.pdf.

VGB PowerTech e.V. 2012. "Entsorgung von Kernkraftwerken: Eine technisch gelöste Aufgabe." Essen. https://www.vgb.org/oppmultimedia/VGB_Brosch_Entsorgung_web-p-758.pdf.

Wealer, Ben, Simon Bauer, Nicolas Landry, Hannah Seiß, and Christian von Hirschhausen. 2018. "Nuclear Power Reactors Worldwide - Technology Developments, Diffusion Patterns, and Country-by- 
Country Analysis of Implementation (1951-2017)." DIW Berlin, Data Documentation 93. Berlin, Germany: DIW Berlin, TU Berlin.

Wieland-Böse, Heike, and Martin Jonas. 2015. "Gutachtliche Stellungnahme zur Bewertung der Rückstellungen im Kernenergiebereich." Düsseldorf: Warth \& Klein Grant Thornton AG. http://www.bmwi.de/BMWi/Redaktion/PDF/S-

T/stresstestkernenergie, property=pdf, bereich=bmwi2012,sprache=de, rwb=true. $p d f$. 